\title{
Bovine herpesvirus 1 infection and infectious bovine rhinotracheitis
}

\author{
Benoît MuYlKens ${ }^{\mathrm{a}}$, Julien THIRYa ${ }^{\mathrm{a}}$, Philippe KIRTEN ${ }^{\mathrm{a}}$, \\ Frédéric SCHYNTS ${ }^{\mathrm{b}}$, Etienne THIRY ${ }^{\mathrm{a} *}$ \\ ${ }^{a}$ Virology, Department of Infectious and Parasitic Diseases, Faculty of Veterinary Medicine, University \\ of Liège, Boulevard de Colonster 20, B43b, 4000 Liège, Belgium \\ ${ }^{\mathrm{b}}$ Department of Animal Virology, CER group, rue du Carmel, 1, 6900 Marloie, Belgium
}

(Received 4 September 2006; accepted 15 November 2006)

\begin{abstract}
Bovine herpesvirus 1 (BoHV-1), classified as an alphaherpesvirus, is a major pathogen of cattle. Primary infection is accompanied by various clinical manifestations such as infectious bovine rhinotracheitis, abortion, infectious pustular vulvovaginitis, and systemic infection in neonates. When animals survive, a life-long latent infection is established in nervous sensory ganglia. Several reactivation stimuli can lead to viral re-excretion, which is responsible for the maintenance of BoHV-1 within a cattle herd. This paper focuses on an updated pathogenesis based on a molecular characterization of BoHV-1 and the description of the virus cycle. Special emphasis is accorded to the impact of the latency and reactivation cycle on the epidemiology and the control of BoHV-1. Several European countries have initiated BoHV-1 eradication schemes because of the significant losses incurred by disease and trading restrictions. The vaccines used against BoHV-1 are described in this context where the differentiation of infected from vaccinated animals is of critical importance to achieve BoHV-1 eradication.
\end{abstract}

alphaherpesvirus / bovine / infectious bovine rhinotracheitis / latency / marker vaccine

\section{Table of contents}

1. Introduction

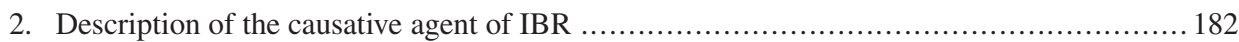

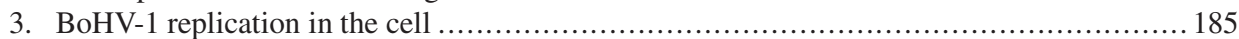

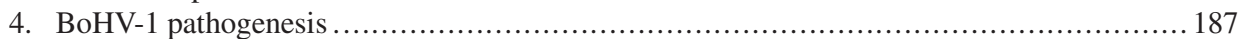

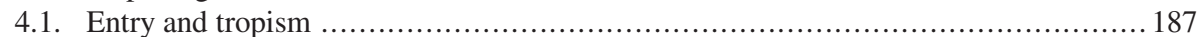

4.2. Replication at the mucosal portal of entry .............................................. 187

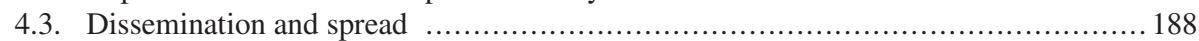

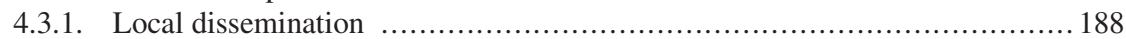

4.3.2. Systemic spread by viremia ................................................. 188

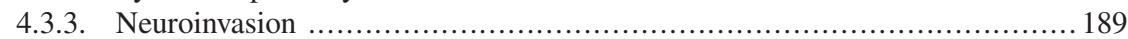

4.4. Immune response and immune evasion strategies ...................................... 190

4.5. The role of BoHV-1 in cattle respiratory disease complex ........................... 192

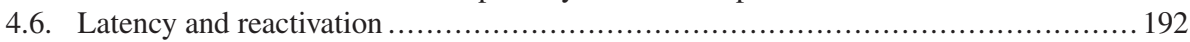

*Corresponding author: etienne.thiry@ulg.ac.be 


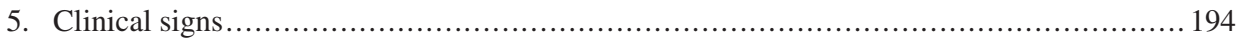

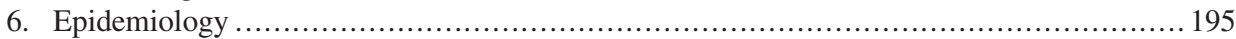

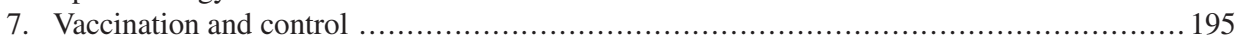

7.1. The DIVA strategy (aiming at differentiating infected from vaccinated animals) ....... 196

7.2. The holy grail in BoHV-1 vaccines: the virological protection........................... 196

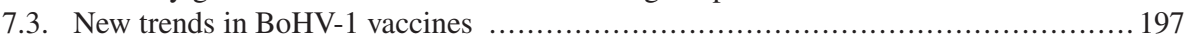

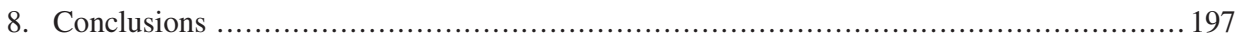

\section{INTRODUCTION}

Büchner and Trommsdorf described in Germany during the 19th century the "Bläschenausschlag" (coïtal vesicular exanthema), a cattle disease probably caused by bovine herpesvirus 1 (BoHV-1). The viral etiology was demonstrated in 1928 by Reisinger and Reimann, who transmitted this venereal disease by a filterable agent. The manifestations of BoHV-1 infections known as "infectious pustular vulvovaginitis" (IPV) in cows and "infectious pustular balanoposthitis" (IPB) in bulls were confined to the genital organs until the early nineteen-fifties. At this time, a respiratory form arose in North American feedlots. This more severe disease due to BoHV-1 infection was called "infectious bovine rhinotracheitis” (IBR) [176]. IBR rapidly spread to Europe when North American dairy cattle were imported in order to improve the milk production performance in Europe.

All BoHV-1 strains isolated hitherto belong to one single viral species, and are classified in three subtypes BoHV-1.1, BoHV-1.2a and BoHV-1.2b. Although most BoHV-1.1 strains have been isolated from respiratory tract diseases or abortion cases and BoHV-1.2 strains from genital organ lesions, the only reliable distinctive criterion is the viral DNA analysis by restriction endonuclease fingerprinting [45, $128,137]$. Indeed, calves infected experimentally by the nasal route with BoHV-1.2 strains showed respiratory clinical signs $[44,190]$ and were able to transmit the respiratory infection to control calves [44, 188]. Otherwise, reproductive tract lesions in heifers were observed after intrauterine inoculation with BoHV-1.1 [134]. Subtypes 1.1 and $1.2 \mathrm{a}$ have been associated with severe diseases including infection of the fetus and abortion [137]. The subtype $1.2 \mathrm{~b}$ was not associated with abortion [43, 187, 216].

BoHV-1 is responsible for significant losses incurred by disease and trading restriction in the cattle industry [14]. Therefore, control programs were rapidly developed after the occurrence of IBR in North American herds. Pending on the level of seroprevalence toward BoHV-1, eradication programs are based either on the detection and the culling of seropositive animals, or on the repeated vaccination of infected herds [2]. Because of the inability of vaccines to prevent BoHV-1 infection and the establishment of latency, BoHV-1 control programs may last for a long period before completing the eradication of this well adapted virus infection of cattle.

\section{DESCRIPTION OF THE CAUSATIVE AGENT OF IBR}

BoHV-1 is one of the eight herpesviruses isolated hitherto from naturally infected cattle (Tab. I). All members of the family Herpesviridae share a common virion morphology based on an icosahedral capsid symmetry, a cell-derived envelope containing virally encoded membrane proteins and a tegument as protein 
Table I. Herpesviruses isolated from naturally infected cattle.

\begin{tabular}{lcl}
\hline Virus species & $\begin{array}{c}\text { Herpesvirus } \\
\text { subfamily }\end{array}$ & Disease following primary infection \\
\hline Cattle as natural host & $\alpha$ & Infectious bovine rhinotracheitis \\
Bovine herpesvirus 1 (BoHV-1) & $\alpha$ & $\begin{array}{l}\text { Bovine mammillitis } \\
\text { Pseudo lumpy skin disease }\end{array}$ \\
Bovine herpesvirus 2(BoHV-2) & $\gamma$ & Not determined \\
& $\alpha$ & Bovine herpesvirus encephalitis \\
Bovine herpesvirus 4 (BoHV-4) & $\gamma$ & Not determined \\
Bovine herpesvirus 5 (BoHV-5) & & \\
Bovine lymphotrophic herpesvirus (BLHV) & $\gamma$ & Malignant catarrhal fever \\
Cattle as foreign host & $\gamma$ & \\
Alcelaphine herpesvirus 1 (AlHV-1) & $\alpha$ & Aujeszky's disease \\
Ovine herpesvirus 2 (OHV-2) & & \\
Suid herpesvirus 1 (SuHV-1) &
\end{tabular}

made matrix connecting the capsid and the envelope. BoHV-1 belongs to the extensive subfamily of Alphaherpesvirinae which contains viruses characterized by a relatively large host range, a short replication cycle and the ability to induce latent infection mainly, but not exclusively, in neurons. Within the Varicellovirus genus, BoHV-1 is related but distinct from several other herpesviruses infecting ruminants. The BoHV-1 genome is made of a long double-stranded linear DNA molecule arranged as a class D genome (Fig. 1). The total size is 135.3 kilo base pairs (kpb). Class D genomes comprise two unique sequences, a unique long $\left(\mathrm{U}_{\mathrm{L}}\right)$ and a unique short $\left(U_{S}\right)$. The latter is bracketed by inverted internal (internal repeat, IR) and terminal (terminal repeat, TR) repeated sequences. During DNA replication, both the $\mathrm{U}_{\mathrm{L}}$ and the $\mathrm{U}_{S}$ regions can flip-flop relative to the other unique region, generating consequently four isomeric forms of the viral genome within the concatemeric DNA [181]. However, a selection process favors the $\mathrm{U}_{\mathrm{L}}$ sequence in the prototype orientation at the level of the cleavage of concatemeric DNA. Therefore, the $\mathrm{U}_{\mathrm{L}}$ is predominantly fixed in one orientation in BoHV-1 virions. Virion DNA include equimolar amounts of two isomers differ- entiated by the inversion of the S segment (Fig. 1).

Despite a guanine and cytosine (GC) content as high as $72 \%$, the entire BoHV-1 sequence was already completed by an international cooperation project in 1995 [91, 107, 130, 178, 179, 186, 213] (Genbank accession number AJ004801). This useful database is a composite sequence obtained from different BoHV-1 strain backgrounds. A total of 73 open reading frames (ORF) have been clearly identified. The majority of the BoHV-1 gene repertoire consists of ORF that are homologous to genes found in other alphaherpesviruses and are generally labelled to the related genes described in the prototype herpes simplex virus 1 (HSV-1). In contrast, one gene is specific to BoHV-1 (UL0.5), whereas some others (e.g. circ gene) are peculiar to the Varicelloviruses [33]. The BoHV-1 genome encloses ten genes encoding glycoproteins (Fig. 1). Among them, six are in the $\mathrm{U}_{\mathrm{L}}, \mathrm{gK}$ (UL53), gC (UL44), gB (UL27), gH (UL22), gM (UL10), gL (UL1) and the four remaining ones are in the $\mathrm{U}_{\mathrm{S}}, \mathrm{gG}$ (UL4), gD (UL6), gI (US7) and gE (US8). UL49.5 can be considered as a false glycoprotein. Indeed, the protein encoded by UL49.5 is not glycosylated in BoHV-1 while it is in other 


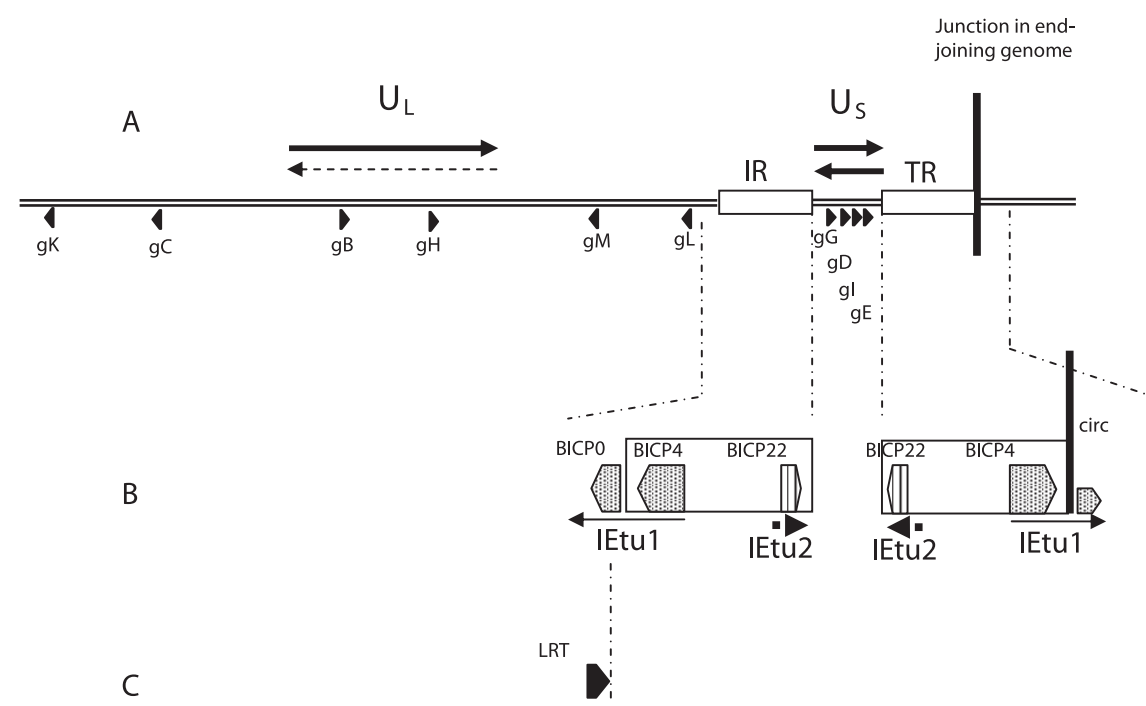

Figure 1. (A) Organization of the BoHV-1 genome including two unique sequences, a long $\left(\mathrm{U}_{\mathrm{L}}\right)$ and a short one $\left(\mathrm{U}_{\mathrm{S}}\right)$. The latter is flanked by two repeated and inverted sequences (internal repeat, IR; terminal repeat, TR). DNA replication generates equimolar amounts of two main isomers that differ by the relative orientation of $U_{S}$ and $U_{L}$ segments (horizontal plain arrows); the latter is predominantly observed in a single orientation. However, low amounts of genome with inverted L segment are observed in BoHV-1 virions (horizontal hatched arrow). The location of the 10 genes encoding BoHV-1 glycoproteins is indicated by black arrow heads. The vertical black bar indicates the junction observed after genome circularization. (B) Schematic view of the two immediate early transcription units (IEtu-1 and -2) whose promoters are located in IR and TR. Activation of the promoter of IEtu1 located in IR leads to the transcription of the BICP4 and BICP0 genes while the activation of the promoter of IEtu1 located in TR leads to the transcription of the BICP4 and circ genes. IEtu2 promoter activation leads to the transcription of the BICP22 gene. (C) Localization of the BoHV-1 region that is actively transcribed during latency giving rise to the Latency Related Transcript (LRT).

alphaherpesviruses (and known as $\mathrm{gN}$ ). Nevertheless, it has a conserved function and forms a disulfide-linked heteroduplex together with gM [115,224]. All BoHV-1 genes are classified into two main categories based on the impact of deletion of a single gene on the ability of mutant virus to grow in cell culture. Nonessential genes are those that allow further growth at least in vitro of the corresponding deletion mutant. Essential genes are genes whose deletion leads to a lethal non replicative BoHV-1 mutant. The classification of a BoHV-1 protein as essential or non-essential is not always definitive and not necessarily conserved in related alphaherpesviruses. Under selective conditions, the function of BoHV-1 gD in direct cell-to-cell spread and entry can be compensated for by mutations in other viral proteins $[111,174,175]$. Moreover, $\mathrm{gD}$ is considered as essential in BoHV-1 while it is not encoded by Varicella-Zoster Virus (VZV) and it is not essential in Marek's disease virus (MDV). On the contrary, gE is known as a non essential protein in BoHV-1 [6, 142, 162] while it is essential in VZV [119]. 


\section{BoHV-1 REPLICATION IN THE CELL}

BoHV-1 infection of permissive cells is initiated by a three steps entry process. The first interaction involves low affinity virus attachment between $\mathrm{gB}$ and/or $\mathrm{gC}$ to cell surface structures like heparan sulfate sugar moieties [109, 110, 113, 151, 152]. This is followed by the stable binding of BoHV-1 gD to cellular specific receptors. An extended array of receptors has been identified as potential targets for $\mathrm{gD}$ interaction in different alphaherpesviruses [22]. Although this large repertoire includes at least four classes of molecules, only nectin-1 (a member of the immunoglobulin superfamily) was demonstrated to serve as entry receptor for BoHV-1 [56]. After this high affinity interaction between $\mathrm{gD}$ and cell receptors, the subsequent virus penetration occurs by fusion of the virion envelope with plasma membrane. This crucial process requires at least the involvement of four BoHV-1 glycoproteins: gD [111,114], $\mathrm{gB}$ [58] and the heterodimer formed by $\mathrm{gH}$ and $\mathrm{gL}$ [131].

Once they have entered the cytosol of a cell, BoHV-1 virus particles must be transported by using dynein motor complex associated with microtubules toward nucleus pores in order to permit viral DNA release. This centripetal cytoplasmic transport in association with microtubules was shown in HSV-1 infected cells and is most likely conserved in alphaherpesviruses [41]. However, the virus protein(s) that mediate(s) this transport is (are) still unknown but is (are) expected to be either viral tegument proteins, or a surface component of the capsid itself $[4,165]$.

While the virus particle is transported to the nucleus, tegument proteins are shed in the cytosol of the infected cell where they might play important roles at early times of virus infection because they are the first to encounter and interact with the intracellular environment. VP8 is the most abundant tegument protein of BoHV-1 [25, 205]. It localizes in the nucleus immediately after infection thanks to a nuclear localization signal [227]. However, the exact role of VP8 in virus infection is still unclear. The tegument protein encoded by UL41 is known as the virion host shutoff (vhs) protein of BoHV-1. Conserved in other alphaherpesviruses, it causes a rapid shutoff of host cell protein synthesis in BoHV-1 infected cells $[76,95]$. Another important tegument protein is VP16 (virion protein 16) known as BoHV-1 $\alpha$-TIF (transinducing factor of alpha genes). It is responsible for the initiation of BoHV-1 gene expression by transactivating BoHV-1 immediate early (IE) genes (alpha genes). BoHV-1 gene expression is temporally regulated during the infection. The cascade of gene expression includes three gene expression kinetics, giving rise to successively IE, early (E), and late (L) RNA [221]. They encode proteins involved respectively and mainly in the regulation of the viral cycle, in the replication of the viral DNA and in the morphogenesis of new virions.

Together with the initiation of gene expression, the BoHV-1 genome is thought to circularize once it enters into the nucleus $[50,53]$. This concept is based on cumulative observations reporting that end-joining genomes were observed in cells infected by several related alphaherpesviruses as for example by HSV-1 [53, 161], VZV [92] and pseudorabies virus (PrV) [85].

The transcription of IE genes is initiated by a complex of VP16 and cellular proteins; the complex binds to a TAATGAGCT motif which is located in the promoter sequences of the two IE transcription units (IEtu1 and IEtu2) of BoHV-1 (Fig. 1) [138, 139, 222, 223]. IEtu1 encodes BICP0, BICP4 [87,178]. Circ, a less abundant transcript, arises from the activation of IEtu1 promoter across the junction of circularized genome and is expressed throughout the viral cycle $[50,51]$. IEtu 2 encodes 
$\mathrm{BICP} 22$. BICP0 is not essential but plays important roles for productive infection because it activates all viral promoters and it is expressed at high levels throughout infection [55, 94, 223]. Although the precise mechanisms of action of bovine IE proteins are not yet completely established [87, 171, 172], the three major IE proteins (BICP0, BICP4, and BICP22) activate E gene expression, and viral DNA replication follows.

The HSV-1 model for herpesvirus DNA replication postulates that the circular genome serves as a template for a first round of theta replication starting from sequences known as origins of replication (ori) [195]. A recent study predicted more precisely the existence of two ori within the inverted repeated sequence surrounding BoHV-1 US [29]. By an unknown mechanism, the theta bidirectional replication step would switch to the rolling circle mode of replication to produce concatemeric DNA. The concatemer is made of a chain of newly synthesized DNA genomes fused in a head-to-tail arrangement [84]. The structure resulting from DNA replication is even more complex because it contains frequent branches. These branched structures are most likely generated by recombination and were observed in concatemeric DNA of HSV-1 [7, 8, 183, 184] and BoHV-1 [181]. Another consequence of the recombination process was detected in BoHV-1 concatemeric DNA. Indeed, four possible arrangements of the adjacent $\mathrm{U}_{\mathrm{L}}$ segment were observed in concatemeric DNA whereas the $\mathrm{U}_{\mathrm{L}}$ of infecting virions is predominantly fixed in one orientation. It is postulated that the sequence inversions are produced by recombination between the IR and the TR surrounding $\mathrm{U}_{\mathrm{L}}$ and $U_{S}$ in the concatemeric DNA [181].

A first wave of late gene expression (early late genes) is initiated during the DNA replication. The second wave (true late genes) is fully dependent on the DNA synthesis. The structural components en- coded by $\mathrm{L}$ genes are required for the synthesis of the new progeny viruses. Assembly of the herpesvirus virion is a complicated process that proceeds along an ordered morphogenetic pathway. Initially the capsid shell proteins assemble in a scaffold-mediated fashion to form an intermediate particle within the nucleus. During maturation, the internal protein scaffold is cleaved and is displaced from inside the capsid as the DNA genome is packaged. Indeed, high-molecular-weight concatemers are cleaved into unit-length genomes by a complex mechanism that is tightly coupled to DNA insertion into the preformed capsid structure. Numerous viral proteins are involved in this cleavagepackaging process and have been reviewed elsewhere [180].

How alphaherpesvirus mature capsids leave nucleus to gain secretory vesicles and how they get their final envelope is a matter of debate. The current view of egress and maturation of alphaherpesviruses proposes a three step model [63, 124-127]. In this model, the primary envelope is acquired by the budding of DNA-containing capsids through the inner nuclear membrane. In order to gain access to the cytoplasm, the virions operate a fusion of their primary envelope with the outer nuclear membrane. A viral kinase activity encoded by US3 is required for this de-envelopment since US3 deletion mutants of HSV-1 [164], PrV [93], and MDV [177] accumulate in the perinuclear space. Once translocated into the cytoplasm, naked capsids definitively acquire their mature tegument and secondary envelope by budding into a presumably trans Golgi compartment [126]. This model of virion maturation and egress was challenged by two alternative routes. The first alternative way involves primary envelopment at the inner nuclear membrane followed by intra-luminal transport through the endoplasmic reticulum and Golgi apparatus secretory pathway [108, 169, 218]. The second alternative route 
of egress involves the dilation of nuclear pores resulting in direct access of capsids to the cytoplasm. Naked capsids would acquire their envelope by budding at any cell membrane [108,218]. Several electron and confocal microscopic observations favoring this route of egress in BoHV-1 [218] and in HSV-1 [108] infected cells emphasize the need for further study in elucidating alphaherpesvirus egress.

\section{BoHV-1 PATHOGENESIS}

\subsection{Entry and tropism}

Natural portal of BoHV-1 entry is the mucous membrane of either upper respiratory or genital tracts. Infection can also be transmitted through inoculation of the conjunctival epithelium. Direct nose to nose contact is the preferential way of transmission of BoHV-1. However, airborne transmissions by the aerosol route were demonstrated on short distances [120]. Genital infection requires direct contact at mating. Genital transmission also occurs through virus contaminated semen [98]. Because of the cryopreservation of the virus infectivity, bulls used for artificial insemination are required to be free of BoHV-1.

To date, there is no molecular basis supporting the tropism of BoHV-1 for genital or respiratory epithelial cells. Although gC is the candidate protein to interact firstly with the host cells $[109,110,112,113,151$, 152], its function in BoHV-1 pathogenesis is not elucidated. Whereas $\mathrm{gC}$ expression was shown as a major determinant for viral replication in the skin and plays a critical role in the virulence of human alphaherpesvirus VZV [140], gC is not essential for BoHV-1 infectivity. Moreover, BoHV-1 $\mathrm{gC}$ mutants retain virulence in the natural host [89]. However, gC may contribute to the differences observed in BoHV-1 subtype tropism. Indeed, differences between HSV-1 $\mathrm{gC}$ and $\mathrm{HSV}-2 \mathrm{gC}$ were shown to influence viral binding properties of the two viruses and could contribute to serotype differences in cell tropism in humans $[57,74]$. Thus, it can reasonably be postulated that variations detected in the $\mathrm{gC}$ of BoHV-1.1 and $-1.2[166,191]$ may account for tropism changes that occurred in strains causing the shift from IPV towards IBR. It is important to specify that these differences are not exclusive because IPV strains inoculated experimentally were able to replicate in the nasal epithelium [44, 188] whereas IBR strains were shown to replicate efficiently in the genital epithelium [134].

\subsection{Replication at the mucosal portal of entry}

Once penetrated into the target epithelial cells, BoHV-1 sets up the lytic replication cycle. It corresponds to the sequential expression of viral genes and leads both to the production of new progeny viruses and to cell death. The BoHV-1 cytopathic effect (CPE) is characterized by the cell ballooning and the rise of intranuclear inclusions. The cell death results both from necrosis and apoptosis processes during the BoHV-1 replication cycle. First evidence of necrosis induced by herpesviruses was shown in HSV-2 infected cells as early as in 1978. It was demonstrated to result from the inhibition of the proteosynthesis [49]. In BoHV-1 infected cells, the cellular protein synthesis is shut off in part by the vhs tegument protein $[76,95]$. By analogy to the HSV-1 UL41 encoded protein, the latter is supposed to degrade mRNA preexisting in the target cell $[48,99]$. Several studies were devoted to the regulation of apoptosis during productive $\mathrm{BoHV}-1$ infection. In a first series of experiments, the effect of BoHV-1 infection was assessed on fresh peripheral blood mononuclear cells (PBMC). Live but also inactivated BoHV-1 induced PBMC apoptosis, suggesting that 
a structural component of BoHV-1 has the capacity to activate the apoptotic process [68]. Moreover, only the attachment of BoHV-1 was able to induce programmed cell death [69]. Glycoprotein D was shown to be involved in this BoHV-1 induced apoptosis [70]. Since PBMC are not the primary target cells of BoHV-1, this model of BoHV-1 induced apoptosis might not reflect the fate of epithelial cells. An immediate onset of apoptosis would decrease BoHV-1 replication at the entry site and prevent therefore its spread. It was also demonstrated that caspase 3, a key regulatory protein in the apoptotic pathway, is activated late during productive $\mathrm{BoHV}-1$ infection $[35,118]$. BICP0 probably participates in this delayed induction of apoptosis by an indirect mechanism that stimulates caspase 3 cleavage [72].

After its participation in direct CPE, BoHV-1 may also reduce the repair of the airway epithelium by inhibiting the migration of new epithelial cells to injured areas. In an in vitro model, BoHV-1 infection had marked effects on the interactions of bronchial epithelial cells with the extracellular matrix, thus decreasing the cell migration [192].

\subsection{Dissemination and spread}

BoHV-1 infection at the natural portal of entry results in massive virus production. New progeny viruses are shed in the nasal mucus at high excretion titers and are responsible for the rapid dissemination of the infection within a cattle herd. The basic reproduction ratio ( $\mathrm{R} 0)$ is a threshold value describing infection dynamics in a population. This parameter is defined as the average number of secondary cases generated by one primary case in a wholly susceptible population of defined density. In experimental conditions, R0 was estimated to be at least 7 in a dairy cattle herd [65]. The new progeny also spreads into the infected animal by using the local dissemination, the systemic spread by viremia and eventually the neuroinvasion [46].

\subsubsection{Local dissemination}

Two different ways allow spreading of the new BoHV-1 generation in the infected mucosa. First, the viruses released in the extra-cellular medium are fully enveloped particles able to interact with the receptors of susceptible cells. Otherwise, viral particles can directly spread from an infected cell to neighboring uninfected cells (direct cell-to-cell spread, ctcs). This way of dissemination is advantageous because it still occurs in the presence of neutralizing antibodies in the extra-cellular medium $[6,162]$. Glycoproteins $\mathrm{gB}, \mathrm{gD}$, and $\mathrm{gH} / \mathrm{gL}$ are required for the ctcs, whereas $\mathrm{gG}$ and the heterodimer formed by $\mathrm{gI} / \mathrm{gE}$ promote the direct ctcs in the prototype alphaherpesvirus HSV-1 $[36,37]$. BoHV-1 $\mathrm{gE}$ and $\mathrm{gG}$ function independently from each other in ctcs; indeed, an additive effect on plaque formation was observed in the $\mathrm{gE} / \mathrm{gG}$ double deletion mutant [201].

\subsubsection{Systemic spread by viremia}

BoHV-1 may spread in the host by viremia, gaining access to a broader range of tissues and organs and causing other clinical manifestations [225] as for example abortion in pregnant cows [136, 137] and fatal systemic infection in very young seronegative calves $[18,75,88,123]$. Very little information is available regarding the mechanism of BoHV-1 systemic spread. Following an intranasal inoculation of a highly virulent BoHV-1 strain, virus was isolated for several days from sera of infected calves, indicating a putative cell-free viremia in some circumstances [88]. Although the cell-associated viremia was extensively described in equine herpesvirus 1 (EHV-1) [3, 202] and PrV [147, 
148] natural infections, this could barely be demonstrated in BoHV-1. Peripheral blood leukocytes were shown in vitro to support BoHV-1 infection and a limited virus replication $[68,150]$, but there is only one univocal report concerning the isolation of infectious BoHV-1 from bovine blood buffy coat after a nasal infection [27]. The positive results in virus isolation attempts obtained on blood buffy coats in several experiments performed by Miller and Whetstone must be carefully interpreted [136, 137, 216, 217]. Rather than using the natural portal of entry to assess BoHV-1 pathogenic properties, the authors introduced an important bias by using the intravenous route in these series of experiments [136, 137, 216, 217].

Finally, the presence of BoHV-1 in peripheral blood leukocytes was supported by PCR assays aiming at the detection of BoHV-1 DNA in naturally infected cattle [52, 144]. However, the results obtained in these studies do not correlate with any positive virus isolation assay. Further studies are needed to define the time window after infection during which BoHV-1 can be detected in peripheral blood leukocytes and to identify eventually the preferential target leukocyte subset used by BoHV-1 for systemic spreading.

\subsubsection{Neuroinvasion}

During the primary virus replication occurring in the mucosal surfaces, BoHV-1 is thought to infect neurons via nerve endings in the mucosae and ascends towards the central nervous system (CNS). The oronasopharyngeal mucosa is innervated by six major brain nerves, from which the nervus olfactorius and nervus trigeminus supply the nasal mucosa. The rostral parts of the nasal cavity are innervated only by the nervus trigeminus, whereas the olfactory epithelium in the caudal parts of the nasal cavity contains both olfactory and trigem- inal nerve endings [58]. These two routes (olfactory and trigeminal) represent the major ways of viral neuroinvasion toward the CNS used by two neurotropic alphaherpesviruses related to BoHV-1: BoHV-5 and PrV. On the contrary, BoHV-1 preferentially uses only the trigeminal way. Moreover, BoHV-1 neuroinvasion usually does not go further than the first order neuron located in the trigeminal ganglion where the latent infection is established. However BoHV-1 was isolated sporadically from cattle with central nervous system disorders $[40,77,168]$. Some of these isolates were shown to be responsible for acute meningo-encephalitis occurring in adult cattle [40,168]. These sporadic cases probably reflect individual host susceptibilities to $\mathrm{CNS}$ infection rather than $\mathrm{BoHV}-1$ strain modifications giving rise to an increased neuroinvasion and/or neurovirulence. Indeed, there was no evidence for specific BoHV-1 DNA restriction patterns associated to these strains isolated from cattle brains whereas the DNA restriction patterns showed clear differences between BoHV-1 and the neuropathogenic strains belonging to BoHV-5 [40,132]. But several host factors may account for increased susceptibility to CNS infection by BoHV-1 as suggested by recent data obtained on sporadic cases of encephalitis caused by HSV-1 in humans [26]. For example, infants possessing homozygous deficiencies in STAT1, a key regulator protein of the antiviral pathway induced by interferons (IFN) $\alpha$ and $\beta$, were shown to be very susceptible to lethal CNS herpesvirus infection $[28,42]$. Otherwise, the apolipoprotein E (Apo E) gene has also been linked to human CNS herpesvirus infections. Three common alleles of Apo E exist in the human population (Apo E2, E3 and E4); among them ApoE4 is less frequent. Infection of transgenic mice expressing the human ApoE4 allele, showed a severe increase of HSV-1 concentration in the brain, compared to wild-type mice, knock-out 
mice in ApoE genes and transgenic mice expressing the ApoE3 allele [20,21]. However, there were no significant differences in the viral levels found in peripheral organs. ApoE4 seems to facilitate the entry and/or spread of HSV-1 in the brain much more efficiently than does E3. It can be reasonably postulated that such kinds of allele susceptibility may explain the BoHV-1 neuroinvasion and/or neurovirulence in individual cattle.

\subsection{Immune response and immune evasion strategies}

Following primary infection, non-specific inflammatory and cellular reactions are the first response to BoHV-1 infection. Some of the non-specific mechanisms are constitutive, such as complement activation whereas others, such as IFN, are induced by virus replication (Tab. II). The production of early cytokines leads to the recruitment and activation of different cells such as macrophages, polymorphonuclear neutrophils and large granular lymphocytes (acting as Natural Killer cells in cattle) (Tab. II). These effectors enhance the first antiviral wave by secreting cytokines in the infected epithelium and killing virus infected cells $[23,24]$. The non specific activated immune cells are also essential in initiating and regulating the specific immune response to $\mathrm{BoHV}-1[5,34]$.

The specific cellular immunity is detected from the 5th day post infection (pi) and reaches a peak at 7-10 days pi. It generally coincides with the recovery of clinical manifestations [5]. Specific T helper lymphocytes mediate the lysis of BoHV-1 infected cells by activating macrophage and NK cells through IFN $\gamma$ and IL2 secretion, and by recruiting and promoting the proliferation of specific cytotoxic $\mathrm{T}$ lymphocytes (Tab. II).

The specific humoral immunity is becoming detectable from day 10 pi. Even if antibodies seem to be less important in the recovery of primary infection, they probably participate in BoHV-1 infection clearance by neutralizing cell free virus particles thus preventing the extracellular spread of infection and by mediating the antibody-dependent cell cytotoxicity. In return the antibody response is of critical importance in preventing secondary infections and limiting the consequences of reactivation [5]. Moreover the passive immunity afforded by colostral antibodies from BoHV-1 immune cows is fully efficacious at protecting the neonate against systemic and lethal disease [123].

Immune evasion strategies: Cattle are able to set up an efficacious immune response following the primary infection with BoHV-1 allowing in most cases recovery from disease and the arrest of virus excretion. Therefore, it is controversial to allocate any role in the BoHV-1 pathogenesis to the several immune evasion mechanisms being described hitherto. Because cattle being infected by BoHV-1 are never able to eliminate the infection and because all the primary BoHV-1 infections are leading to a life-long latent infection, we can speculate that these immune evasion strategies might play a role in facilitating BoHV-1 to establish a persistent infection (Tab. II).

Recent data showed that BICP0 inhibits the transcription of type I IFN [73]. This inhibition of innate antiviral signaling is induced by the degradation of IRF3 (IFN regulatory factor 3 ), a protein involved in the regulatory complex ensuring transcription of type I IFN [170]. BoHV-1 possesses another evasion strategy to soluble factors of the innate immune response. Conserved in related alphaherpesviruses such as $\mathrm{PrV}$, EHV-1 and HSV-1, this evasion mechanism is mediated by the interaction of $\mathrm{gC}$ with the third complement component (C3), the key mediator of complement activation [79]. Another immunomodulatory function conserved in alphaherpesvirus has 
Table II. Description of the components of the immune response and the immune evasion strategies during BoHV-1 infection.

\begin{tabular}{|c|c|c|c|}
\hline \multicolumn{2}{|c|}{ Components of the immune response } & \multirow{2}{*}{$\begin{array}{l}\text { BoHV-1 immune evasion strategies } \\
\text { Down-regulation of type I-IFN by BICP0 } \\
\text { Chemokine binding activity of gG }\end{array}$} & \multirow{2}{*}{$\begin{array}{c}\text { Reference } \\
{[73,170]} \\
{[19]}\end{array}$} \\
\hline $\begin{array}{l}\text { Soluble factors of the } \\
\text { innate immunity }\end{array}$ & $\begin{array}{l}\text { Type I-IFN } \\
\text { Chemokines }\end{array}$ & & \\
\hline & $\begin{array}{l}\text { Alternate complement } \\
\text { pathway }\end{array}$ & Interaction of $\mathrm{gC}$ with bovine $\mathrm{C} 3 \mathrm{~b}$ & [79] \\
\hline \multirow[t]{3}{*}{$\begin{array}{l}\text { Cells of the innate } \\
\text { immunity }\end{array}$} & $\begin{array}{l}\text { Monocytes- } \\
\text { macrophages }\end{array}$ & PBMC apoptosis & $\begin{array}{l}{[68,69,} \\
70]\end{array}$ \\
\hline & $\begin{array}{l}\text { Polymorphonuclear } \\
\text { cells }\end{array}$ & $\begin{array}{l}\text { Interference with alveolar macrophages and } \\
\text { PMN activities }\end{array}$ & {$[17,215]$} \\
\hline & $\begin{array}{l}\text { Large Granular } \\
\text { Lymphocytes }\end{array}$ & & \\
\hline \multirow[t]{3}{*}{ Antigen presentation } & MHC class I pathway & $\begin{array}{l}\text { Inhibition of TAP by UL } 49.5 \\
\text { Decrease of MHC class I }\end{array}$ & {$[95,96]$} \\
\hline & & Presentation by UL41 (vhs) & [76] \\
\hline & MHC class II pathway & $\begin{array}{l}\text { Decrease of MHC class II presentation by } \\
\text { UL41 (vhs) }\end{array}$ & [76] \\
\hline \multirow[t]{2}{*}{$\begin{array}{l}\text { Adaptive immune } \\
\text { cells }\end{array}$} & $\begin{array}{l}\text { Helper T lymphocytes } \\
(\mathrm{CD} 4+)\end{array}$ & Infection and apoptosis of CD4+ & [219] \\
\hline & $\begin{array}{l}\text { Cytotoxic T } \\
\text { lymphocytes (CD8+) } \\
\text { B cells }\end{array}$ & $\begin{array}{l}\text { Down-regulation of MHC class I impairs the } \\
\text { activation of CD8+ }\end{array}$ & [96] \\
\hline \multirow[t]{2}{*}{$\begin{array}{l}\text { Adaptive humoral } \\
\text { factors }\end{array}$} & Antibodies & $\begin{array}{l}\text { The direct } c t c s^{*} \text { mediated by } \mathrm{gB}, \mathrm{gD}, \mathrm{gH} / \\
\mathrm{gL}, \mathrm{gE} / \mathrm{gI} \text { allow spreading of BoHV-1 in the } \\
\text { presence of neutralizing Abs }\end{array}$ & [201] \\
\hline & $\begin{array}{l}\text { Classical complement } \\
\text { pathway }\end{array}$ & Interaction of $\mathrm{gC}$ with bovine $\mathrm{C} 3 \mathrm{~b}$ & [79] \\
\hline $\begin{array}{l}\text { Apoptosis of the } \\
\text { infected cells }\end{array}$ & & $\begin{array}{l}\text { Latency related gene inhibits apoptosis in } \\
\text { latently infected cells }\end{array}$ & [31] \\
\hline
\end{tabular}

*ctcs: cell-to-cell spread.

been identified through the interaction of gG with several chemokines [19,32]. Both soluble and membrane-anchored forms of BoHV-1 $\mathrm{gG}$ function as broad-spectrum chemokine binding proteins.

In order to diminish the detection and the elimination of virus-infected cells by cytotoxic $\mathrm{T}$ lymphocytes, BoHV-1 was shown to down-regulate antigen presentation by the class I major histocompatibility complex (MHC class I) [95, 96, 115, 146]. Two independent mechanisms are responsible for down-regulation of MHC class I molecules. UL49.5 by blocking the transporter associated with antigen processing (TAP) [96] and vhs protein (encoded by UL41) [95] act together in this inhibition. But they are not able to completely prevent the immune detection of BoHV-1 infected cells. 


\subsection{The role of BoHV-1 in cattle respiratory disease complex}

Cattle respiratory disease complex is a multifactorial disease caused by multiple deleterious management practices, and interactions among viral and bacterial pathogens. Experimental evidence and field observations supported the involvement of BoHV-1 infection in promoting bacterial superinfections leading to severe bronchopneumonia [145]. The modifications induced by BoHV-1 may act at three levels of the physiological responses to pathogens.

- Epithelium damages caused by BoHV-1 infection reduce the mucosal clearance due to mucous secretion and ciliary activities [198].

- BoHV-1 infections can diminish the activities of alveolar macrophages and polymorphonuclear neutrophils [17, 103,215]. It can also cause a selective depletion of $\mathrm{CD}^{+}$lymphocyte populations, and changes in leukocyte trafficking [215, 219].

- Another possible mechanism that might explain BoHV-1/bacterial synergism is the exposure of leukocytes to inflammatory cytokines released in response to BoHV-1 infection $[101,102]$.

\subsection{Latency and reactivation}

After primary infection with BoHV-1, cattle become latent carriers. BoHV-1 establishes lifelong latency in sensory neurons of the peripheral nervous system after replication in mucosal epithelium. By analogy to its $\mathrm{HSV}$ and PrV alphaherpesvirus homologues, BoHV-1 is thought to penetrate the terminus of the sensitive nerves distributed in the infected epithelium [47]. It is then transported along the microtubules of the axons to reach the neuron body in the nervous ganglion. Although the main site of latency is ganglionic neurons, there is evidence that latency and reactivation occur within germinal centers of pharyngeal tonsils [220].

As stated above, a well-regulated transcription cascade of alpha, beta and gamma BoHV-1 genes leads to the activation of caspases and p53 resulting in programmed cell death and efficient virion release in permissive cells. The BICP0 IE gene plays a key role in this lytic phase $[35,72]$. On the contrary, in latently infected neurons, only the BoHV-1 region containing the latency-related transcript (LRT) is expressed leading to the inhibition of the lytic virus cycle and the induction of an antiapoptotic state of the infected cells (Fig. 1) [71]. This observation suggests that DNA sequences in the LR promoter are positively regulated by neural cell type factors. This is evidenced by a different localization of the start site for the LR RNA in lytic infections and latent infection in trigeminal ganglion [16,78]. A fraction of the BoHV-1 LR transcript is polyadenylated and alternatively spliced in latently infected cells, suggesting that these transcripts are translated in several LR products (LRP). A protein corresponding to the $\mathrm{N}$-terminus of ORF2 in LRT was detected in high amounts during latency by western blotting $[78,86]$. Recently, another peptide, designated ORF-E, was shown to be abundantly expressed in trigeminal ganglion of latently infected calves [82]. No role in the latency-reactivation cycle of BoHV-1 has been currently associated to this small ORF.

Different functions have been attributed to the LRT: inhibition of apoptosis [31], inhibition of the $S$ phase entry [173] and inhibition of BICP0 expression [54]. LRP expression is required for inhibiting apoptosis but protein expression does not seem to be necessary for inhibiting cell growth or BICP0 expression [87]. Several in vivo studies were performed to investigate the role of LRT and LRP during productive and latent infections. The 
infection of calves with LRT non sense mutants showed a less severe clinical picture and a reduced virus shedding from eyes, tonsils or trigeminal ganglions when compared to the infection with wild-type or the LRT rescued BoHV-1. The LRT mutants were shed at similar rates from the nasal cavity during the primary infection $[80,158]$. In latently infected neurons, reduced levels of viral DNA were detected [81] but higher levels of apoptosis occurred in trigeminal ganglion at the end of the acute infection [118]. The BoHV-1 LRT mutants were not re-excreted following a reactivation treatment with dexamethasone, which induced reactivation and re-excretion in all calves infected by either wild-type or LRT rescued virus [81]. Moreover a chimeric HSV-1 mutant where the BoHV-1 LR gene replaces the deleted Latency Associated Transcript locus of HSV-1 presents a high level of spontaneous reactivation in the rabbit eye model [159]. Altogether, these results indicate that the LR gene is required for the BoHV-1 latency-reactivation cycle. It is obviously demonstrated that the LR gene protects neurons from cell death during establishment of latency. The cell death inhibition would also be necessary to maintain the latency by keeping alive the latently infected neurons. No mechanism currently explains the role of the LR gene in the reactivation and/or the re-excretion of BoHV-1.

By analogy to observations obtained in HSV latency and reactivation, the immune system is believed to play a role in the regulation of the BoHV-1 latency-reactivation cycle. In a HSV latency mice model, cytotoxic $\mathrm{T}$ lymphocytes producing IFN- $\gamma$ were shown to be able to prevent reactivation from latency in sensory neurons [116]. Another study concluded that IFN- $\alpha$ and $-\gamma$ act as control factors of recurrent herpetic lesions [133]. However, no data presently support the involvement of any viral protein in the regulation of the immune response during latency.
Reactivation from latency can occur after natural stimulus exposure [193, 194] or corticosteroid treatment [185] culminating in recurrent virus transmission to uninfected animals generally without clinical signs. Once reactivated in the neurons of the trigeminal ganglion, BoHV-1 initiates a new replication cycle. Dexamethasone induced reactivation performed on latently infected rabbits showed that only a small proportion of latently infected neurons underwent successful reactivation and that viral DNA specific of the productive BoHV-1 infection was detected as early as 18 hours post treatment [167]. Progeny viruses are thought to reach the primary site of entry through the axonal pathway. At the level of this mucosal epithelium, virus amplification will or will not give rise to BoHV-1 re-excretion. Two factors were shown to influence the virus re-excretion: the preimmune status and the progeny virus phenotype. (i) The primary immune response acquired following a BoHV-1 natural exposure or a vaccination scheme is able to successfully control the re-excretion of any latent carrier. The secondary immune response boosted by successive reactivation stimulus is also effective at inhibiting virus re-excretion [155]. Therefore, reactivation stimulus occurring in the first two months following the primary infection is not expected to give rise to virus reexcretion. Moreover, animals having the highest titres of BoHV-1 neutralizing antibodies before the reactivation will not re-excrete any virus following an efficacious reactivation treatment [13]. (ii) The progeny virus phenotype has an influence on the ability for a virus to be re-excreted or not. Recent experiments demonstrated that a BoHV-1 gC-gE- null mutant established latency but was not re-excreted following a reactivation treatment [143]. Otherwise, several gE-null BoHV-1 recombinants issued from virulent BoHV-1 were re-excreted. But in comparison with the calves infected by wild-type BoHV-1 
a lower proportion of calves infected with the gE-null virus re-excreted and a temporal delay of three days was observed in the period of re-excretion. This result indicates that the progeny virus phenotype may influence the BoHV-1 re-excretion properties [143]. However and on the contrary to what is observed in the related HSV-1, a thymidine kinase deficient mutant of BoHV-1 is re-excreted from latency following reactivation treatment [217].

\section{CLINICAL SIGNS}

The severity of the disease caused by BoHV-1 is influenced by several factors such as the virulence of the BoHV-1 strain [88], resistance factors of the host, especially the age, and potential concurrent bacterial infection.

Subclinical BoHV-1 infections are common. Several BoHV-1 strains display a poor ability to induce clinical signs and were classified as weakly virulent strains in a comparative virulence experiment [88]. Otherwise, these discrete clinical pictures can also be explained by the primary infection of passively immune calves in countries where BoHV-1 is endemic. Indeed, colostral immunity is known to protect efficiently infected animals from clinical signs $[105,123]$.

Following the intranasal inoculation of seronegative calves, high fever is measured for 4 to 5 days (peak at $41{ }^{\circ} \mathrm{C}$ ) and may be accompanied by apathy and anorexia. Adult dairy cows show a significant milk drop during that period $[67,208]$. After 2 to 3 days of incubation, respiratory and ocular signs are observed. They are consistent with the inflammatory response and the epithelium damages caused by BoHV-1 at primary replication sites. They consist of red appearance of nasal mucosa, serous to mucopurulent nasal discharge, and in severe cases heavy breathing at inspiration (tracheal stridor caused by necrotic debris in the tracheal lumen) and cough. An endoscopy examination revealed a red appearance of pharyngeal and tracheal mucosal epithelia and the presence of several necrotic foci recovered with dead mucosal epithelial cells embedded in fibrinous exudate [143]. Ocular signs such as conjunctivitis and mucopurulent ocular shedding are not uncommon.

Abortion is a consequence of a respiratory BoHV-1 infection of a seronegative cow. Naturally occurring BoHV-1 abortions are usually observed at 4 to 8 months of gestation although experimental virus parenteral inoculation of heifers prior to 3 months induce embryonic death $[30,135]$. Using the systemic spread by viremia, BoHV-1 must cross the maternalfetal barrier to produce lethal infection of the fetus $[30,154]$. The route of BoHV-1 from the placenta to the fetus is unknown but since viral lesions are consistently observed in the fetal liver, haematogenous spread occurs most likely via the umbilical vein. The incubation period between inoculation with BoHV-1 and abortion is 15 to 64 days. Although the lesions are observed both in the placenta and in several fetal organs, it was suggested that placental degeneration would be secondary to the fetal death induced by BoHV-1 [141]. As stated above only BoHV-1.1 and BoHV-1.2a strains have been so far associated with abortigenic potential $[137,156]$.

Neonatal calves may experience multisystemic infection following congenital infection prior to birth or early postnatal BoHV-1 infection [18, 75, 88, 123]. Colostrum-deprived calves are especially at risk [123]. Excessive salivation and diarrhea are consecutive to BoHV-1 replication in the epithelium of digestive organs that are not common targets for BoHV-1. Several lesions are observed in the digestive tract such as glossitis, esophagitis and acute necrotizing rumenitis. The outcome is fatal within four to five days; calves die in a moribund state. 
The BoHV-1 genital form is usually transmitted at mating. The names given to the diseases affecting the cow (infectious pustular vulvovaginitis, IPV) and the bull (infectious pustular balanoposthitis, IPB) describe clearly the clinical pictures observed following the primary infection. Although the infection is restricted to the genital organs, more severe infection leading to orchitis in the bull and endometritis in the cow have occasionally been reported [59].

\section{EPIDEMIOLOGY}

BoHV-1 is a worldwide disseminated pathogen displaying significant differences in regional incidence and prevalence with regards to the geographical positions and the breeding managements of the considered regions [2].

Based on serological surveys, several studies have been aimed at identifying the risk factors for BoHV-1 seropositivity. Some of them are well characterized such as the following: age, sex (males are more frequently positive than females) and herd size [10,189]. Direct animal contact, such as purchase of cattle and participation in cattle shows were also found to be important risk factors for the introduction of BoHV-1 [209-211]. Other factors such as farm density or cattle density may increase the risk of BoHV-1 introduction [214].

As reported for other diseases caused by herpesviruses in man and animals the latency reactivation cycle has a deep epidemiological impact since it is responsible for the maintenance of BoHV-1 in a cattle population. BoHV-1 infection of new generation cattle by latent carriers submitted to reactivation stimulus may occur at several occasions as for example at birth [193], mating, during transport [194] or following the introduction of heifers into the group of dairy cows. Therefore the detection of BoHV-1 latent carriers is a concern in the setting up of a BoHV-1 control program.
The identification of latently infected animals is commonly based on the detection of BoHV-1-specific antibodies. However, passively acquired colostral immunity may interfere with an active antibody response following infection $[15,104]$. As a consequence one seronegative $\mathrm{BoHV}-1$ latent carrier (SNLC) was obtained 7 months after experimental infection of passively immunized calves with a virulent BoHV-1 [105]. It is therefore imperative to develop other diagnostic tests that can detect such latently infected animals. The direct PCR identification of BoHV-1 from tonsil samples would be a useful alternative [220].

Another concern in BoHV-1 eradication schemes rose from the capacity for BoHV-1 to cross the species barrier. Field data and experimental infections have brought evidence of possible infections of several ruminant species with BoHV-1. But there is no indication so far that non cattle ruminant species could play a role of alternative reservoir of BoHV-1. In the natural situation BoHV-1 was detected in acutely and latently infected sheep. However sheep do not play a major role in the transmission of BoHV-1 to cattle [66]. Successful BoHV-1 infections were experimentally obtained in sheep and goats. Red deer exhibit a limited susceptibility to BoHV-1 [197]. Otherwise the experimental host range of BoHV-1 is rather narrow. Rabbits can be infected via the intraconjunctival or the intranasal route [129]. Mice are not susceptible to the infection. Fully susceptible mice to BoHV-1 infection were obtained by introducing combined genetic deficiencies in the ability to produce IFN$\alpha / \beta$ receptor or IFN- $\gamma$ receptor in a genetic background unable to produce mature $\mathrm{B}$ and T lymphocytes [1].

\section{VACCINATION AND CONTROL}

The aims in controlling BoHV-1 infection have evolved along the past decades 
from an easily obtained reduction of the clinical impact towards a more difficult prevention of virus transmission. BoHV-1 vaccines are sorted into four categories: modified live, inert (inactivated and subunit), DNA and vector based vaccines. Vaccination against BoHV-1 was recently reviewed in an exhaustive way [206]. Therefore we prefer to focus on some of the challenges that were either successfully achieved or not yet resolved.

\subsection{The DIVA strategy (aiming at differentiating infected from vaccinated animals)}

Several European countries have initiated control programs aimed at BoHV-1 eradication and based on the use of marker vaccines deleted in the $\mathrm{gE}$ gene. These marker vaccines, either inactivated or live attenuated, used together with a serological detection of $\mathrm{gE}$-specific antibodies, allow discriminating infected from vaccinated animals $[100,212]$. This capacity of differentiation is critical for trading restriction. The efficacy of the DIVA (differentiation of infected from vaccinated animals) vaccines was demonstrated in two field trials. In the first trial, a significant decrease of the number of $\mathrm{gE}$ seroconversion was observed in herds where the $\mathrm{gE}$ deleted vaccines were used [122]. The second study demonstrated that repeated vaccination protocols using either inactivated or live attenuated $\mathrm{gE}$ deleted BoHV-1 vaccines are efficacious at reducing the incidence of $\mathrm{gE}$ seroconversion in dairy cattle and consequently the herd prevalence of $\mathrm{gE}$ positive animals [39]. This study pointed out the increased efficacy of the repeated vaccination at regular six month intervals at the herd level in comparison with punctual vaccination of some part of the herds [39]. Even if the DIVA strategy was demonstrated to be efficacious, it presents some weaknesses [9]. Indeed the strength of the tool is fully dependent on the capacity of the diagnostic test at detecting BoHV-1 gE specific antibody. But the sensitivity of the only available $\mathrm{gE}$ specific ELISA is around $70 \%$ $[97,160]$. This rather low level of sensitivity is responsible for $30 \%$ false negative answers at individual tests but it remains sufficient to guarantee a high sensitivity at the level of infected herds. The second disadvantage of this test is due to the weak level of the immune response raised against BoHV-1 gE. Consequently the time window for the ability of this test to detect $\mathrm{gE}$ antibodies can be delayed for up to 42 days [9]. Finally, one can also mention two biosafety concerns about the live attenuated $\mathrm{gE}$ deleted vaccine. First $\mathrm{gE}$ null BoHV-1 was demonstrated to establish a latent infection [106,207] and to be re-excreted both under experimental stimulus [106, 182] and in field conditions [38]. However there is so far no indication for a possible perpetuation of this deletion mutant in the cattle population [121]. A second concern is the potential rise of BoHV-1 recombinants issued from coinfection situations involving a replicative $\mathrm{gE}$ deleted BoHV-1 and a virulent field BoHV-1 strain $[195,196]$. One field observation and two experimental data underlie this concern: (i) the isolation of a $\mathrm{gE}$ deleted BoHV-1 vaccine strain in cows vaccinated eight months before [38]; (ii) the frequent rise of BoHV-1 recombinants in coinfected calves [182] and (iii) the isolation of a virulent $\mathrm{gE}$ deleted BoHV-1 recombinant under experimental conditions $[142,143]$.

\subsection{The holy grail in BoHV-1 vaccines: the virological protection}

Most vaccines are very efficacious at preventing the clinical signs after the challenge with highly virulent strains. But no one is able to fully prevent the infection by that challenge strain, which establishes a latent infection, and might be reexcreted under reactivation stimulus. New 
vaccine formulations and protocols were therefore developed in order to improve the impairment of BoHV-1 excretion and re-excretion. Equivocal results have been obtained when the two forms (inactivated and live attenuated) of the same marker vaccine were tested. When it was administrated two times to seronegative cattle, the attenuated marker vaccine induced a better virological protection than the inactivated marker vaccines after challenge [11]. However, the inactivated vaccine was more efficacious at reducing virus excretion after reactivation of latently infected calves than the live attenuated one [12]. An interesting approach consisted in combining the attenuated vaccine as priming injection and the inactivated vaccine as boost injection to complete the primary vaccination. This kind of protocol was shown to be the most efficacious at reducing the virus excretion following challenge [90].

As stated above, the immune status of a BoHV-1 latent carrier is the key factor controlling the virus re-excretion under reactivation stimulus. Therefore the vaccination of latent carriers must be carefully addressed by repeated vaccination schemes at regular six month intervals in order to decrease to a maximum the risk of reexcretion [39].

\subsection{New trends in BoHV-1 vaccines}

Several studies were conducted and are still in progress to set up new generation vaccines. Ideal vaccines would combine the safety and efficacy issues. Several subunit vaccines were tested. They consist mainly of glycoproteins B, C or $\mathrm{D}$ expressed in different systems such as transfected cell cultures [204], recombinant baculoviruses [203], recombinant adenoviruses [60, 62, 163, 226], or recombinant tobacco mosaïc virus [157]. The gD based subunit vaccines are the most efficacious at reducing clinical disease and virus excretion when they are formulated with effective adjuvants. For example, chitosans [61] and CpG oligodeoxynucleotide [83, 149] are new adjuvants that significantly enhance the protective immune response as evidenced by increased neutralizing antibody titers and reduced clinical diseases and viral shedding following challenge.

The latest vaccine approaches consist of plasmid DNA vaccines containing sequences encoding for the three major immunodominant BoHV-1 glycoproteins $\mathrm{gC}$ [64], gB [117] or gD [153,199, 200]. These constructs raised the putative vaccination of cattle by needle free delivery methods which would be advantageous to avoid losses due to tissue damage encountered by classical vaccine delivery methods $[83$, 206].

\section{CONCLUSIONS}

As a member of the Herpesviridae family BoHV-1 most likely co-evolved for a long time period with its host species. The large gene content enables BoHV-1 to complete a well regulated virus cycle and to infect neuronal cells where it can establish a latent infection. As a consequence BoHV-1 is a well adapted virus in its bovine host. It is also prevalent all over the world. Under particular breeding circumstances and in cases of introduction of BoHV-1 in a naïve herd, BoHV-1 is the causative agent of a severe and highly contagious respiratory disease, infectious bovine rhinotracheitis. Abortion and fatal systemic diseases in neonates are the most severe consequences of respiratory infections with virulent strains. The BoHV-1 vaccines are effective at reducing the clinical impact of BoHV-1 infection. However no vaccine is able to prevent the infection and the establishment of latency by challenge and field strains. Therefore the programs aiming at BoHV-1 eradication are using the DIVA strategy. Synergistic medical and sanitary measures are needed 
to control the epidemiological risk due to the presence of BoHV-1 latent carriers. The goal of the vaccination is to prevent their capacity to re-excrete BoHV-1 by repeated vaccination. When the prevalence of latent carriers is low, it is safer to cull them. The detection of BoHV-1 latently infected animals has to be improved in this context. Moreover, sanitary measures must be taken to prevent the introduction of BoHV-1 seropositive animals or even animals originating from a seropositive herd in order to improve the efficacy of control programs.

\section{ACKNOWLEDGEMENTS}

Benoît Muylkens is a FNRS research follow.

\section{REFERENCES}

[1] Abril C., Engels M., Liman A., Hilbe M., Albini S., Franchini M., Suter M., Ackermann M., Both viral and host factors contribute to neurovirulence of bovine herpesviruses 1 and 5 in interferon receptordeficient mice, J. Virol. (2004) 78:36443653 .

[2] Ackermann M., Engels M., Pro and contra IBR-eradication, Vet. Microbiol. (2006) 113:293-302.

[3] Allen G.P., Breathnach C.C., Quantification by real-time PCR of the magnitude and duration of leucocyte-associated viraemia in horses infected with neuropathogenic vs. non-neuropathogenic strains of EHV-1, Equine Vet. J. (2006) 38:252-257.

[4] Antinone S.E., Shubeita G.T., Coller K.E., Lee J.I., Haverlock-Moyns S., Gross S.P., Smith G.A., The Herpesvirus capsid surface protein, VP26, and the majority of the tegument proteins are dispensable for capsid transport toward the nucleus, J. Virol. (2006) 80:5494-5498.

[5] Babiuk L.A., van Drunen Littel-van den Hurk S., Tikoo S.K., Immunology of bovine herpesvirus 1 infection, Vet. Microbiol. (1996) 53:31-42.
[6] Baranowski E., Keil G., Lyaku J., Rijsewijk F.A., van Oirschot J.T., Pastoret P.P., Thiry E., Structural and functional analysis of bovine herpesvirus 1 minor glycoproteins, Vet. Microbiol. (1996) 53:91-101.

[7] Bataille D., Epstein A., Herpes simplex virus replicative concatemers contain $\mathrm{L}$ components in inverted orientation, Virology (1994) 203:384-388.

[8] Bataille D., Epstein A.L., Equimolar generation of the four possible arrangements of adjacent L components in herpes simplex virus type 1 replicative intermediates, J. Virol. (1997) 71:7736-7743.

[9] Beer M., Konig P., Schielke G., Trapp S., Diagnostic markers in the prevention of bovine herpesvirus type 1: possibilities and limitations, Berl. Munch. Tierarztl. Wochenschr. (2003) 116:183-191.

[10] Boelaert F., Speybroeck N., de Kruif A., Aerts M., Burzykowski T., Molenberghs G., Berkvens D.L., Risk factors for bovine herpesvirus-1 seropositivity, Prev. Vet. Med. (2005) 69:285-295.

[11] Bosch J.C., Kaashoek M.J., Kroese A.H., van Oirschot J.T., An attenuated bovine herpesvirus 1 marker vaccine induces a better protection than two inactivated marker vaccines, Vet. Microbiol. (1996) 52:223-234.

[12] Bosch J.C., Kaashoek M.J., van Oirschot J.T., Inactivated bovine herpesvirus 1 marker vaccines are more efficacious in reducing virus excretion after reactivation than a live marker vaccine, Vaccine (1997) 15:1512-1517.

[13] Bosch J.C., De Jong M.C.M., Franken P., Frankena K., Hage J.J., Kaashoek M.J., Maris-Veldhuis M.A., Noordhuizen J.P.T.M., Van der Poel W.H.M., Verhoeff J., Weerdmeester K., Zimmer G.M., Van Oirschot J.T., An inactivated gE-negative marker vaccine and an experimental gDsubunit vaccine reduce the incidence of bovine herpesvirus 1 infections in the field, Vaccine (1998) 16:265-271.

[14] Bowland S.L., Shewen P.E., Bovine respiratory disease: commercial vaccines currently available in Canada, Can. Vet. J. (2000) 41:33-48.

[15] Bradshaw B.J., Edwards S., Antibody isotype responses to experimental infection with bovine herpesvirus 1 in calves with colostrally derived antibody, Vet. Microbiol. (1996) 53:143-151. 
[16] Bratanich A.C., Jones C.J., Localization of cis-acting sequences in the latency-related promoter of bovine herpesvirus 1 which are regulated by neuronal cell type factors and immediate-early genes, J. Virol. (1992) 66:6099-6106.

[17] Brown T.T. Jr., Ananaba G., Effect of respiratory infections caused by bovine herpesvirus-1 or parainfluenza-3 virus on bovine alveolar macrophage functions, Am. J. Vet. Res. (1988) 49:1447-1451.

[18] Bryan L.A., Fenton R.A., Misra V., Haines D.M., Fatal, generalized bovine herpesvirus type-1 infection associated with a modified-live infectious bovine rhinotracheitis parainfluenza-3 vaccine administered to neonatal calves, Can. Vet. J. (1994) 35:223-228.

[19] Bryant N.A., Davis-Poynter N., Vanderplasschen A., Alcami A., Glycoprotein $G$ isoforms from some alphaherpesviruses k, EMBO J. (2003) 22:833-846.

[20] Burgos J.S., Ramirez C., Sastre I., Bullido M.J., Valdivieso F., ApoE4 is more efficient than E3 in brain access by herpes simplex virus type 1, Neuroreport. (2003) 14:18251827.

[21] Burgos J.S., Ramirez C., Sastre I., Valdivieso F., Effect of apolipoprotein $\mathrm{E}$ on the cerebral load of latent herpes simplex virus type 1 DNA, J. Virol. (2006) 80:5383-5387.

[22] Campadelli-Fiume G., Cocchi F., Menotti L., Lopez M., The novel receptors that mediate the entry of herpes simplex viruses and animal alphaherpesviruses into cells, Rev. Med. Virol. (2000) 10:305-319.

[23] Campos M., Rossi C.R., Cytotoxicity of bovine lymphocytes after treatment with lymphokines, Am. J. Vet. Res. (1986) 47:1524-1528.

[24] Campos M., Ohmann H.B., Hutchings D., Rapin N., Babiuk L.A., Lawman M.J., Role of interferon-gamma in inducing cytotoxicity of peripheral blood mononuclear leukocytes to bovine herpesvirus type 1 (BHV-1)-infected cells, Cell. Immunol. (1989) 120:259-269.

[25] Carpenter D.E., Misra V., The most abundant protein in bovine herpes 1 virions is a homologue of herpes simplex virus type 1 UL47, J. Gen. Virol. (1991) 72:3077-3084.
[26] Casrouge A., Zhang S.Y., Eidenschenk C., Jouanguy E., Puel A., Yang K., Alcais A., Picard C., Mahfoufi N., Nicolas N., Lorenzo L., Plancoulaine S., Senechal B., Geissmann F., Tabeta K., Hoebe K., Du X., Miller R.L., Heron B., Mignot C., de Villemeur T.B., Lebon P., Dulac O., Rozenberg F., Beutler B., Tardieu M., Abel L., Casanova J.L., Herpes simplex virus encephalitis in human UNC-93B deficiency, Science (2006) 314:308-312.

[27] Castrucci G., Ferrari M., Traldi V., Tartaglione E., Effects in calves of mixed infections with bovine viral diarrhea virus and several other bovine viruses, Comp. Immunol. Microbiol. Infect. Dis. (1992) 15:261-270.

[28] Chapgier A., Wynn R.F., Jouanguy E., Filipe-Santos O., Zhang S., Feinberg J., Hawkins K., Casanova J.L., Arkwright P.D., Human complete Stat-1 deficiency is associated with defective type I and II IFN responses in vitro but immunity to some low virulence viruses in vivo, J. Immunol. (2006) 176:5078-5083.

[29] Chew D.S., Choi K.P., Leung M.Y., Scoring schemes of palindrome clusters for more sensitive prediction of replication origins in herpesviruses, Nucleic Acids Res. (2005) 33:e134.

[30] Chow T.L., Molello J.A., Owen N.V., Abortion experimentally induced in cattle by infectious bovine rhinotracheitis virus, J. Am. Vet. Med. Assoc. (1964) 144:10051007.

[31] Ciacci-Zanella J., Stone M., Henderson G., Jones C., The latency-related gene of bovine herpesvirus 1 inhibits programmed cell death, J. Virol. (1999) 73:9734-9740.

[32] Costes B., Ruiz-Arguello M.B., Bryant N.A., Alcami A., Vanderplasschen A., Both soluble and membrane-anchored forms of Felid herpesvirus 1 glycoprotein $\mathrm{G}$ function as a broad-spectrum chemokine-binding protein, J. Gen. Virol. (2005) 86:32093214.

[33] Delhon G., Moraes M.P., Lu Z., Afonso C.L., Flores E.F., Weiblen R., Kutish G.F., Rock D.L., Genome of bovine herpesvirus 5, J. Virol. (2003) 77:10339-10347.

[34] Denis M., Splitter G., Pastoret P.-P., Babiuk L.A., Infectious bovine rhinotracheitis (bovine herpesvirus 1): helper $\mathrm{T}$ cells, cytotoxic T cells and NK cells, CRC Press, Boca Raton, 1994. 
[35] Devireddy L.R., Jones C.J., Activation of caspases and p53 by bovine herpesvirus 1 infection results in programmed cell death and efficient virus release, J. Virol. (1999) 73:3778-3788.

[36] Dingwell K.S., Brunetti C.R., Hendricks R.L., Tang Q., Tang M., Rainbow A.J., Johnson D.C., Herpes simplex virus glycoproteins $\mathrm{E}$ and I facilitate cell-to-cell spread in vivo and across junctions of cultured cells, J. Virol. (1994) 68:834-845.

[37] Dingwell K.S., Doering L.C., Johnson D.C., Glycoproteins E and I facilitate neuron-to-neuron spread of herpes simplex virus, J. Virol. (1995) 69:7087-7098.

[38] Dispas M., Schynts F., Lemaire M., Letellier C., Vanopdenbosch E., Thiry E., Kerkhofs P., Isolation of a glycoprotein Edeleted bovine herpesvirus type 1 strain in the field, Vet. Rec. (2003) 153:209-212.

[39] Dispas M., Lemaire M., Speybroeck N., Berkvens D., Dupont A., Boelart F., Dramaix M., Vanopdenbosch E., Kerkhofs P., Thiry E., Deux protocoles d'hyperimmunisation au moyen de vaccins marqués réduisent l'incidence de séroconversion envers l'herpèsvirus bovin 1 en cheptels laitiers : résultats d'une étude sur le terrain, Ann. Med. Vet. (2004) 148:47-61.

[40] D’Offay J.M., Mock R.E., Fulton R.W., Isolation and characterization of encephalitic bovine herpesvirus type 1 isolates from cattle in North America, Am. J. Vet. Res. (1993) 54:534-539.

[41] Dohner K., Wolfstein A., Prank U., Echeverri C., Dujardin D., Vallee R., Sodeik B., Function of dynein and dynactin in herpes simplex virus capsid transport, Mol. Biol. Cell (2002) 13:2795-2809.

[42] Dupuis S., Jouanguy E., Al-Hajjar S., Fieschi C., Al-Mohsen I.Z., Al-Jumaah S., Yang K., Chapgier A., Eidenschenk C., Eid P., Al Ghonaium A., Tufenkeji H., Frayha H., Al-Gazlan S., Al-Rayes H., Schreiber R.D., Gresser I., Casanova J.L., Impaired response to interferon-alpha/beta and lethal viral disease in human STAT1 deficiency, Nat. Genet. (2003) 33:388-391.

[43] Edwards S., White H., Nixon P., A study of the predominant genotypes of bovid herpesvirus 1 found in the UK, Vet. Microbiol. (1990) 22:213-223.

[44] Edwards S., Newman R.H., White H., The virulence of British isolates of bovid her- pesvirus 1 in relationship to viral genotype, Br. Vet. J. (1991) 147:216-231.

[45] Engels M., Steck F., Wyler R., Comparison of the genomes of infectious bovine rhinotracheitis and infectious pustular vulvovaginitis virus strains by restriction endonuclease analysis, Arch. Virol. (1981) 67:169-174.

[46] Engels M., Ackermann M., Pathogenesis of ruminant herpesvirus infections, Vet. Microbiol. (1996) 53:3-15.

[47] Enquist L.W., Husak P.J., Banfield B.W., Smith G.A., Infection and spread of alphaherpesviruses in the nervous system, Adv. Virus Res. (1998) 51:237-347.

[48] Esclatine A., Taddeo B., Evans L., Roizman B., The herpes simplex virus 1 UL41 gene-dependent destabilization of cellular RNAs is selective and may be sequencespecific, Proc. Natl. Acad. Sci. USA (2004) 101:3603-3608.

[49] Fenwick M.L., Walker M.J., Suppression of the synthesis of cellular macromolecules by herpes simplex virus, J. Gen. Virol. (1978) 41:37-51.

[50] Fraefel C., Wirth U.V., Vogt B., Schwyzer M., Immediate-early transcription over covalently joined genome ends of bovine herpesvirus 1: the circ gene, J. Virol. (1993) 67:1328-1333.

[51] Fraefel C., Ackermann M., Schwyzer M., Identification of the bovine herpesvirus 1 circ protein, a myristylated and virionassociated polypeptide which is not essential for virus replication in cell culture, J. Virol. (1994) 68:8082-8088.

[52] Fuchs M., Hubert P., Detterer J., Rziha H.J., Detection of bovine herpesvirus type 1 in blood from naturally infected cattle by using a sensitive PCR that discriminates between wild-type virus and virus lacking glycoprotein E, J. Clin. Microbiol. (1999) 37:2498-2507.

[53] Garber D.A., Beverley S.M., Coen D.M., Demonstration of circularization of herpes simplex virus DNA following infection using pulsed field gel electrophoresis, Virology (1993) 197:459-462.

[54] Geiser V., Inman M., Zhang Y., Jones C., The latency-related gene of bovine herpesvirus-1 can inhibit the ability of bICP0 to activate productive infection, J. Gen. Virol. (2002) 83:2965-2971. 
[55] Geiser V., Zhang Y., Jones C., Analysis of a bovine herpesvirus 1 recombinant virus that does not express the bICP0 protein, J. Gen. Virol. (2005) 86:1987-1996.

[56] Geraghty R.J., Krummenacher C., Cohen G.H., Eisenberg R.J., Spear P.G., Entry of alphaherpesviruses mediated by poliovirus receptor-related protein 1 and poliovirus receptor, Science (1998) 280:1618-1620.

[57] Gerber S.I., Belval B.J., Herold B.C., Differences in the role of glycoprotein $\mathrm{C}$ of HSV-1 and HSV-2 in viral binding may contribute to serotype differences in cell tropism, Virology (1995) 214:29-39.

[58] Gerdts V., Beyer J., Lomniczi B., Mettenleiter T.C., Pseudorabies virus expressing bovine herpesvirus 1 glycoprotein B exhibits altered neurotropism and increased neurovirulence, J. Virol. (2000) 74:817-827.

[59] Gibbs E.P., Rweyemamu M.M., Bovine herpesviruses. Part I. Bovine herpesvirus 1, Vet. Bull. (1977) 47:317-343.

[60] Gogev S., Vanderheijden N., Lemaire M., Schynts F., D’Offay J., Deprez I., Adam M., Eloit M., Thiry E., Induction of protective immunity to bovine herpesvirus type 1 in cattle by intranasal administration of replication-defective human adenovirus type 5 expressing glycoprotein $\mathrm{gC}$ or $\mathrm{gD}$, Vaccine (2002) 20:1451-1465.

[61] Gogev S., de Fays K., Versali M.F., Gautier S., Thiry E., Glycol chitosan improves the efficacy of intranasally administrated replication defective human adenovirus type 5 expressing glycoprotein D of bovine herpesvirus 1, Vaccine (2004) 22:1946-1953.

[62] Gogev S., Georgin J.P., Schynts F., Vanderplasschen A., Thiry E., Bovine herpesvirus 1 glycoprotein D expression in bovine upper respiratory tract mediated by a human adenovirus type 5 , Vet. Res. (2004) 35:715-721.

[63] Granzow H., Klupp B.G., Fuchs W., Veits J., Osterrieder N., Mettenleiter T.C., Egress of alphaherpesviruses: comparative ultrastructural study, J. Virol. (2001) 75:36753684.

[64] Gupta P.K., Saini M., Gupta L.K., Rao V.D., Bandyopadhyay S.K., Butchaiah G., Garg G.K., Garg S.K., Induction of immune responses in cattle with a DNA vaccine encoding glycoprotein C of bovine herpesvirus-1, Vet. Microbiol. (2001) 78:293-305.
[65] Hage J.J., Schukken Y.H., Barkema H.W., Benedictus G., Rijsewijk F.A., Wentink G.H., Population dynamics of bovine herpesvirus 1 infection in a dairy herd, Vet. Microbiol. (1996) 53:169-180.

[66] Hage J.J., Vellema P., Schukken Y.H., Barkema H.W., Rijsewijk F.A., van Oirschot J.T., Wentink G.H., Sheep do not have a major role in bovine herpesvirus 1 transmission, Vet. Microbiol. (1997) 57:41-54.

[67] Hage J.J., Schukken Y.H., Dijkstra T., Barkema H.W., van Valkengoed P.H., Wentink G.H., Milk production and reproduction during a subclinical bovine herpesvirus 1 infection on a dairy farm, Prev. Vet. Med. (1998) 34:97-106.

[68] Hanon E., Vanderplasschen A., Lyaku S., Keil G., Denis M., Pastoret P.P., Inactivated bovine herpesvirus 1 induces apoptotic cell death of mitogen-stimulated bovine peripheral blood mononuclear cells, J. Virol. (1996) 70:4116-4120.

[69] Hanon E., Meyer G., Vanderplasschen A., Dessy-Doize C., Thiry E., Pastoret P.P., Attachment but not penetration of bovine herpesvirus 1 is necessary to induce apoptosis in target cells, J. Virol. (1998) 72:76387641.

[70] Hanon E., Keil G., van Drunen Littel-van den Hurk S., Griebel P., Vanderplasschen A., Rijsewijk F.A., Babiuk L., Pastoret P.P., Bovine herpesvirus 1-induced apoptotic cell death: role of glycoprotein D, Virology (1999) 257:191-197.

[71] Henderson G., Perng G.C., Nesburn A.B., Wechsler S.L., Jones C., The latencyrelated gene encoded by bovine herpesvirus 1 can suppress caspase 3 and caspase 9 cleavage during productive infection, $\mathrm{J}$. Neurovirol. (2004) 10:64-70.

[72] Henderson G., Zhang Y., Inman M., Jones D., Jones C., Infected cell protein 0 encoded by bovine herpesvirus 1 can activate caspase 3 when overexpressed in transfected cells, J. Gen. Virol. (2004) 85:3511-3516.

[73] Henderson G., Zhang Y., Jones C., The Bovine herpesvirus 1 gene encoding infected cell protein 0 (bICP0) can inhibit interferon-dependent transcription in the absence of other viral genes, J. Gen. Virol. (2005) 86:2697-2702.

[74] Herold B.C., Gerber S.I., Belval B.J., Siston A.M., Shulman N., Differences in the 
susceptibility of herpes simplex virus types 1 and 2 to modified heparin compounds suggest serotype differences in viral entry, J. Virol. (1996) 70:3461-3469.

[75] Higgins R.J., Edwards S., Systemic neonatal infectious bovine rhinotracheitis virus infection in suckler calves, Vet. Rec. (1986) 119:177-178.

[76] Hinkley S., Ambagala A.P., Jones C.J., Srikumaran S., A vhs-like activity of bovine herpesvirus-1, Arch. Virol. (2000) 145:2027-2046.

[77] Horiuchi M., Yamazaki N., Furuoka H., Matsui T., Nakagawa M., Ishiguro N., Shinagawa M., Restriction endonuclease analysis of bovine herpesvirus type 1 isolates from calves with fatal encephalitis: comparison with vaccine virus, J. Vet. Med. Sci. (1995) 57:577-580

[78] Hossain A., Schang L.M., Jones C., Identification of gene products encoded by the latency-related gene of bovine herpesvirus 1, J. Virol. (1995) 69:5345-5352.

[79] Huemer H.P., Larcher C., van Drunen Littel-van den Hurk S., Babiuk L.A., Species selective interaction of Alphaherpesvirinae with the "unspecific" immune system of the host, Arch. Virol. (1993) 130:353-364

[80] Inman M., Lovato L., Doster A., Jones C., A mutation in the latency-related gene of bovine herpesvirus 1 leads to impaired ocular shedding in acutely infected calves, J. Virol. (2001) 75:8507-8515.

[81] Inman M., Lovato L., Doster A., Jones C., A mutation in the latency-related gene of bovine herpesvirus 1 disrupts the latency reactivation cycle in calves, J. Virol. (2002) 76:6771-6779.

[82] Inman M., Zhou J., Webb H., Jones C., Identification of a novel bovine herpesvirus 1 transcript containing a small open reading frame that is expressed in trigeminal ganglia of latently infected cattle, J. Virol. (2004) 78:5438-5447.

[83] Ioannou X.P., Griebel P., Hecker R., Babiuk L.A., van Drunen Littel-van den Hurk S., The immunogenicity and protective efficacy of bovine herpesvirus 1 glycoprotein $\mathrm{D}$ plus Emulsigen are increased by formulation with $\mathrm{CpG}$ oligodeoxynucleotides, J. Virol. (2002) 76:9002-9010.

[84] Jacob R.J., Morse L.S., Roizman B., Anatomy of herpes simplex virus DNA.
XII. Accumulation of head-to-tail concatemers in nuclei of infected cells and their role in the generation of the four isomeric arrangements of viral DNA, J. Virol. (1979) 29:448-457.

[85] Jean J.H., Ben-Porat T., Appearance in vivo of single-stranded complementary ends on parental herpesvirus DNA, Proc. Natl. Acad. Sci. USA (1976) 73:2674-2678.

[86] Jiang Y., Hossain A., Winkler M.T., Holt T., Doster A., Jones C., A protein encoded by the latency-related gene of bovine herpesvirus 1 is expressed in trigeminal ganglionic neurons of latently infected cattle and interacts with cyclin-dependent kinase 2 during productive infection, J. Virol. (1998) 72:8133-8142.

[87] Jones C., Geiser V., Henderson G., Jiang Y., Meyer F., Perez S., Zhang Y., Functional analysis of bovine herpesvirus 1 (BHV-1) genes expressed during latency, Vet. Microbiol. (2006) 113:199-210.

[88] Kaashoek M.J., Straver P.H., Van R.E., Quak J., van Oirschot J.T., Virulence, immunogenicity and reactivation of seven bovine herpesvirus 1.1 strains: clinical and virological aspects, Vet. Rec. (1996) 139:416-421.

[89] Kaashoek M.J., Rijsewijk F.A., Ruuls R.C., Keil G.M., Thiry E., Pastoret P.P., van Oirschot J.T., Virulence, immunogenicity and reactivation of bovine herpesvirus 1 mutants with a deletion in the $\mathrm{gC}, \mathrm{gG}, \mathrm{gI}$, $\mathrm{gE}$, or in both the $\mathrm{gI}$ and $\mathrm{gE}$ gene, Vaccine (1998) 16:802-809.

[90] Kerkhofs P., Renjifo X., Toussaint J.F., Letellier C., Vanopdenbosch E., Wellemans G., Enhancement of the immune response and virological protection of calves against bovine herpesvirus type 1 with an inactivated gE-deleted vaccine, Vet. Rec. (2003) 152:681-686.

[91] Khattar S.K., van Drunen Littel-van den Hurk S., Babiuk L.A., Tikoo S.K., Identification and transcriptional analysis of a 3'-coterminal gene cluster containing UL1, UL2, UL3, and UL3.5 open reading frames of bovine herpesvirus-1, Virology (1995) 213:28-37.

[92] Kinchington P.R., Reinhold W.C., Casey T.A., Straus S.E., Hay J., Ruyechan W.T., Inversion and circularization of the varicella-zoster virus genome, J. Virol. (1985) 56:194-200. 
[93] Klupp B.G., Granzow H., Mettenleiter T.C., Effect of the pseudorabies virus US3 protein on nuclear membrane localization of the UL34 protein and virus egress from the nucleus, J. Gen. Virol. (2001) 82:23632371.

[94] Koppel R., Fraefel C., Vogt B., Bello L.J., Lawrence W.C., Schwyzer M., Recombinant bovine herpesvirus-1 (BHV-1) lacking transactivator protein BICPO entails lack of glycoprotein $\mathrm{C}$ and severely reduced infectivity, Biol. Chem. (1996) 377:787-795.

[95] Koppers-Lalic D., Rijsewijk F.A., Verschuren S.B., van Gaans-Van den Brink J.A., Neisig A., Ressing M.E., Neefjes J., Wiertz E.J., The UL41-encoded virion host shutoff (vhs) protein and vhs-independent mechanisms are responsible for down-regulation of MHC class I molecules by bovine herpesvirus $1, \mathrm{~J}$. Gen. Virol. (2001) 82:2071-2081.

[96] Koppers-Lalic D., Reits E.A., Ressing M.E., Lipinska A.D., Abele R., Koch J., Marcondes Rezende M., Admiraal P., van Leeuwen D., Bienkowska-Szewczyk K., Mettenleiter T.C., Rijsewijk F.A., Tampe R., Neefjes J., Wiertz E.J., Varicelloviruses avoid $\mathrm{T}$ cell recognition by UL49.5mediated inactivation of the transporter associated with antigen processing, Proc. Natl. Acad. Sci. USA (2005) 102:51445149.

[97] Kramps J.A., Banks M., Beer M., Kerkhofs P., Perrin M., Wellenberg G.J., van Oirschot J.T., Evaluation of tests for antibodies against bovine herpesvirus 1 performed in national reference laboratories in Europe, Vet. Microbiol. (2004) 102:169-181.

[98] Kupferschmied H.U., Kihm U., Bachmann P., Müller K.H., Ackermann M., Transmission of IBR/IPV virus in bovine semen: A case report, Theriogenology (1986) 25:439-443.

[99] Kwong A.D., Frenkel N., Herpes simplex virus-infected cells contain a function(s) that destabilizes both host and viral mRNAs, Proc. Natl. Acad. Sci. USA (1987) 84:1926-1930.

[100] Lehmann D., Sodoyer R., Leterme S., Crevat D., Improvement of serological discrimination between herpesvirus-infected animals and animals vaccinated with marker vaccines, Vet. Microbiol. (2002) 86:59-68.
[101] Leite F., Sylte M.J., O’Brien S., Schultz R., Peek S., van Reeth K., Czuprynski C.J., Effect of experimental infection of cattle with bovine herpesvirus-1 (BHV-1) on the ex vivo interaction of bovine leukocytes with Mannheimia (Pasteurella) haemolytica leukotoxin, Vet. Immunol. Immunopathol. (2002) 84:97-110.

[102] Leite F., Kuckleburg C., Atapattu D., Schultz R., Czuprynski C.J., BHV-1 infection and inflammatory cytokines amplify the interaction of Mannheimia haemolytica leukotoxin with bovine peripheral blood mononuclear cells in vitro, Vet. Immunol. Immunopathol. (2004) 99:193-202.

[103] Leite F., Atapattu D., Kuckleburg C., Schultz R., Czuprynski C.J., Incubation of bovine PMNs with conditioned medium from BHV-1 infected peripheral blood mononuclear cells increases their susceptibility to Mannheimia haemolytica leukotoxin, Vet. Immunol. Immunopathol. (2005) 103:187-193.

[104] Lemaire M., Meyer G., Baranowski E., Schynts F., Wellemans G., Kerkhofs P., Thiry E., Production of bovine herpesvirus type 1-seronegative latent carriers by administration of a live-attenuated vaccine in passively immunized calves, J. Clin. Microbiol. (2000) 38:4233-4238.

[105] Lemaire M., Weynants V., Godfroid J., Schynts F., Meyer G., Letesson J.J., Thiry E., Effects of bovine herpesvirus type 1 infection in calves with maternal antibodies on immune response and virus latency, J. Clin. Microbiol. (2000) 38:1885-1894.

[106] Lemaire M., Schynts F., Meyer G., Georgin J.P., Baranowski E., Gabriel A., Ros C., Belak S., Thiry E., Latency and reactivation of a glycoprotein $\mathrm{E}$ negative bovine herpesvirus type 1 vaccine: influence of virus load and effect of specific maternal antibodies, Vaccine (2001) 19:4795-4804.

[107] Leung-Tack P., Audonnet J.C., Riviere M., The complete DNA sequence and the genetic organization of the short unique region (US) of the bovine herpesvirus type 1 (ST strain), Virology (1994) 199:409-421.

[108] Leuzinger H., Ziegler U., Schraner E.M., Fraefel C., Glauser D.L., Heid I., Ackermann M., Mueller M., Wild P., Herpes simplex virus 1 envelopment follows two diverse pathways, J. Virol. (2005) 79:13047-13059. 
[109] Li Y., van Drunen Littel-van den Hurk S., Babiuk L.A., Liang X., Characterization of cell-binding properties of bovine herpesvirus 1 glycoproteins $\mathrm{B}, \mathrm{C}$, and $\mathrm{D}$ : identification of a dual cell-binding function of gB, J. Virol. (1995) 69:4758-4768.

[110] Liang X., Babiuk L.A., Zamb T.J., An in vivo study of a glycoprotein gIII-negative bovine herpesvirus 1 (BHV-1) mutant expressing beta-galactosidase: evaluation of the role of gIII in virus infectivity and its use as a vector for mucosal immunization, Virology (1992) 189:629-639.

[111] Liang X., Pyne C., Li Y., Babiuk L.A., Kowalski J., Delineation of the essential function of bovine herpesvirus $1 \mathrm{gD}$ : an indication for the modulatory role of $\mathrm{gD}$ in virus entry, Virology (1995) 207:429-441.

[112] Liang X., Chow B., Babiuk L.A., Study of immunogenicity and virulence of bovine herpesvirus 1 mutants deficient in the UL49 homolog, UL49.5 homolog and dUTPase genes in cattle, Vaccine (1997) 15:10571064.

[113] Liang X.P., Babiuk L.A., van Drunen Littelvan den Hurk S., Fitzpatrick D.R., Zamb T.J., Bovine herpesvirus 1 attachment to permissive cells is mediated by its major glycoproteins gI, gIII, and gIV, J. Virol. (1991) 65:1124-1132.

[114] Ligas M.W., Johnson D.C., A herpes simplex virus mutant in which glycoprotein $\mathrm{D}$ sequences are replaced by betagalactosidase sequences binds to but is unable to penetrate into cells, J. Virol. (1988) 62:1486-1494.

[115] Lipinska A.D., Koppers-Lalic D., Rychlowski M., Admiraal P., Rijsewijk F.A., Bienkowska-Szewczyk K., Wiertz E.J., Bovine herpesvirus 1 UL49.5 protein inhibits the transporter associated with antigen processing despite complex formation with glycoprotein M, J. Virol. (2006) 80:5822-5832.

[116] Liu T., Khanna K.M., Chen X., Fink D.J., Hendricks R.L., CD8(+) T cells can block herpes simplex virus type 1 (HSV-1) reactivation from latency in sensory neurons, J. Exp. Med. (2000) 191:1459-1466.

[117] Loehr B.I., Willson P., Babiuk L.A., van Drunen Littel-van den Hurk S., Gene gunmediated DNA immunization primes development of mucosal immunity against bovine herpesvirus 1 in cattle, J. Virol. (2000) 74:6077-6086.
[118] Lovato L., Inman M., Henderson G., Doster A., Jones C., Infection of cattle with a bovine herpesvirus 1 strain that contains a mutation in the latency-related gene leads to increased apoptosis in trigeminal ganglia during the transition from acute infection to latency, J. Virol. (2003) 77:4848-4857.

[119] Mallory S., Sommer M., Arvin A.M., Analysis of the glycoproteins I and E of varicella-zoster virus (VZV) using deletional mutations of VZV cosmids, J. Infect. Dis. (1998) 178:S22-26.

[120] Mars M.H., de Jong M.C., van Maanen C., Hage J.J., van Oirschot J.T., Airborne transmission of bovine herpesvirus 1 infections in calves under field conditions, Vet. Microbiol. (2000) 76:1-13.

[121] Mars M.H., de Jong M.C., van Oirschot J.T., A gE-negative BHV1 vaccine virus strain cannot perpetuate in cattle populations, Vaccine (2000) 18:2120-2124.

[122] Mars M.H., de Jong M., Franken P., van Oirschot J.T., Efficacy of a live glycoprotein E-negative bovine herpesvirus 1 vaccine in cattle in the field, Vaccine (2001) 19:19241930.

[123] Mechor G.D., Rousseaux C.G., Radostits O.M., Babiuk L.A., Petrie L., Protection of newborn calves against fatal multisystemic infectious bovine rhinotracheitis by feeding colostrum from vaccinated cows, Can. J. Vet. Res. (1987) 51:452-459.

[124] Mettenleiter T.C., Herpesvirus assembly and egress, J. Virol. (2002) 76:1537-1547.

[125] Mettenleiter T.C., Intriguing interplay between viral proteins during herpesvirus assembly or: the herpesvirus assembly puzzle, Vet. Microbiol. (2006) 113:163-169.

[126] Mettenleiter T.C., Klupp B.G., Granzow H., Herpesvirus assembly: a tale of two membranes, Curr. Opin. Microbiol. (2006) 9:423-429.

[127] Mettenleiter T.C., Minson T., Egress of alphaherpesviruses, J. Virol. (2006) 80:16101611; author reply 1611-1612.

[128] Metzler A.E., Matile H., Gassmann U., Engels M., Wyler R., European isolates of bovine herpesvirus 1: a comparison of restriction endonuclease sites, polypeptides, and reactivity with monoclonal antibodies, Arch. Virol. (1985) 85:57-69.

[129] Meyer G., Lemaire M., Lyaku J., Pastoret P.P., Thiry E., Establishment of a rabbit 
model for bovine herpesvirus type 5 neurological acute infection, Vet. Microbiol. (1996) 51:27-40.

[130] Meyer G., Vlcek C., Paces V., O’Hara M.K., Pastoret P.P., Thiry E., Schwyzer M., Sequence analysis of the bovine herpesvirus type 1 genes homologous to the DNA polymerase (UL30), the major DNAbinding protein (UL29) and ICP18.5 assembly protein (UL28) genes of herpes simplex virus, Arch. Virol. (1997) 142:89102.

[131] Meyer G., Hanon E., Georlette D., Pastoret P.P., Thiry E., Bovine herpesvirus type 1 glycoprotein $\mathrm{H}$ is essential for penetration and propagation in cell culture, J. Gen. Virol. (1998) 79:1983-1987.

[132] Meyer G., Lemaire M., Ros C., Belak K., Gabriel A., Cassart D., Coignoul F., Belak S., Thiry E., Comparative pathogenesis of acute and latent infections of calves with bovine herpesvirus types 1 and 5, Arch. Virol. (2001) 146:633-652.

[133] Mikloska Z., Cunningham A.L., Alpha and gamma interferons inhibit herpes simplex virus type 1 infection and spread in epidermal cells after axonal transmission, J. Virol. (2001) 75:11821-11826.

[134] Miller J.M., Van der Maaten M.J., Reproductive tract lesions in heifers after intrauterine inoculation with infectious bovine rhinotracheitis virus, Am. J. Vet. Res. (1984) 45:790-794.

[135] Miller J.M., Van der Maaten M.J., Experimentally induced infectious bovine rhinotracheitis virus infection during early pregnancy: effect on the bovine corpus luteum and conceptus, Am. J. Vet. Res. (1986) 47:223-228.

[136] Miller J.M., Whetstone C.A., Bello L.J., Lawrence W.C., Determination of ability of a thymidine kinase-negative deletion mutant of bovine herpesvirus-1 to cause abortion in cattle, Am. J. Vet. Res. (1991) 52:1038-1043.

[137] Miller J.M., Whetstone C.A., Van der Maaten M.J., Abortifacient property of bovine herpesvirus type 1 isolates that represent three subtypes determined by restriction endonuclease analysis of viral DNA, Am. J. Vet. Res. (1991) 52:458-461.

[138] Misra V., Bratanich A.C., Carpenter D., O'Hare P., Protein and DNA elements involved in transactivation of the promoter of the bovine herpesvirus (BHV) 1 IE-1 transcription unit by the BHV alpha gene transinducing factor, J. Virol. (1994) 68:48984909.

[139] Misra V., Walker S., Hayes S., O'Hare P., The bovine herpesvirus alpha gene transinducing factor activates transcription by mechanisms different from those of its herpes simplex virus type 1 counterpart VP16, J. Virol. (1995) 69:5209-5216.

[140] Moffat J.F., Zerboni L., Kinchington P.R., Grose C., Kaneshima H., Arvin A.M., Attenuation of the vaccine Oka strain of varicella-zoster virus and role of glycoprotein $\mathrm{C}$ in alphaherpesvirus virulence demonstrated in the SCID-hu mouse, J. Virol. (1998) 72:965-974.

[141] Molello J.A., Chow T.L., Owen N., Jensen R., Placental pathology. V. Placental lesions of cattle experimentally infected with infectious bovine rhinotracheitis virus, Am. J. Vet. Res. (1966) 27:907-915.

[142] Muylkens B., Meurens F., Schynts F., de Fays K., Pourchet A., Thiry J., Vanderplasschen A., Antoine N., Thiry E., Biological characterization of bovine herpesvirus 1 recombinants possessing the vaccine glycoprotein E negative phenotype, Vet. Microbiol. (2006) 113:283-291.

[143] Muylkens B., Meurens F., Schynts F., Farnir F., Pourchet A., Bardiau M., Gogev S., Thiry J., Cuisenaire A., Vanderplasschen A., Thiry E., Intraspecific bovine herpesvirus 1 recombinants carrying glycoprotein $\mathrm{E}$ deletion as a vaccine marker are virulent in cattle, J. Gen. Virol. (2006) 87:2149-2154.

[144] Mweene A.S., Okazaki K., Kida H., Detection of viral genome in non-neural tissues of cattle experimentally infected with bovine herpesvirus 1, Jpn. J. Vet. Res. (1996) 44:165-174.

[145] Narita M., Kimura K., Tanimura N., Arai S., Tsuboi T., Katsuda K., Immunohistochemical characterization of calf pneumonia produced by the combined endobronchial administration of bovine herpesvirus 1 and Pasteurella haemolytica, J. Comp. Pathol. (2000) 123:126-134.

[146] Nataraj C., Eidmann S., Hariharan M.J., Sur J.H., Perry G.A., Srikumaran S., Bovine herpesvirus 1 downregulates the expression of bovine MHC class I molecules, Viral Immunol. (1997) 10:21-34. 
[147] Nauwynck H.J., Pensaert M.B., Abortion induced by cell-associated pseudorabies virus in vaccinated sows, Am. J. Vet. Res. (1992) 53:489-493.

[148] Nauwynck H.J., Pensaert M.B., Effect of specific antibodies on the cell-associated spread of pseudorabies virus in monolayers of different cell types, Arch. Virol. (1995) 140:1137-1146.

[149] Nichani A.K., Mena A., Kaushik R.S., Mutwiri G.K., Townsend H.G., Hecker R., Krieg A.M., Babiuk L.A., Griebel P.J., Stimulation of innate immune responses by $\mathrm{CpG}$ oligodeoxynucleotide in newborn lambs can reduce bovine herpesvirus-1 shedding, Oligonucleotides (2006) 16:5867.

[150] Nyaga P.N., McKercher D.G., Pathogenesis of bovine herpesvirus-1 (BHV-1) infections: interactions of the virus with peripheral bovine blood cellular components, Comp. Immunol. Microbiol. Infect. Dis. (1979) 2:587-602.

[151] Okazaki K., Honda E., Kono Y., Expression of bovine herpesvirus 1 glycoprotein gIII by a recombinant baculovirus in insect cells, J. Gen. Virol. (1994) 75:901-904.

[152] Okazaki K., Honda E., Kono Y., Heparinbinding domain of bovid herpesvirus 1 glycoprotein gIII, Arch. Virol. (1994) 134:413-419.

[153] Oliveira S.C., Harms J.S., Rosinha G.M., Rodarte R.S., Rech E.L., Splitter G.A., Biolistic-mediated gene transfer using the bovine herpesvirus-1 glycoprotein D is an effective delivery system to induce neutralizing antibodies in its natural host, J. Immunol. Methods (2000) 245:109-118.

[154] Owen N.V., Chow T.L., Molello J.A., Bovine fetal lesions experimentally produced by infectious bovine rhinotracheitis virus, Am. J. Vet. Res. (1964) 25:16171626.

[155] Pastoret P.P., Aguilar-Setien A., Burtonboy G., Mager J., Jetteur P., Schoenaers F., Effect of repeated treatment with dexamethasone on the reexcretion pattern of infectious bovine rhinotracheitis virus and humoral immune response, Vet. Microbiol. (1979) 4:149-159.

[156] Pauli G., Gregersen J.P., Storz J., Ludwig H., Biology and molecular biology of latent bovine herpes virus type 1 (BHV-1), in: Wittmann G., Gaskell R.M., Rziha H.J.
(Eds.), Latent herpesvirus infections in veterinary medicine, Brussels-Luxembourg, Martinus Nijhoff Publishers, 1982, pp. 229-239.

[157] Perez Filgueira D.M., Zamorano P.I., Dominguez M.G., Taboga O., Del Medico Zajac M.P., Puntel M., Romera S.A., Morris T.J., Borca M.V., Sadir A.M., Bovine herpes virus $\mathrm{gD}$ protein produced in plants using a recombinant tobacco mosaic virus (TMV) vector possesses authentic antigenicity, Vaccine (2003) 21:4201-4209.

[158] Perez S., Inman M., Doster A., Jones C., Latency-related gene encoded by bovine herpesvirus 1 promotes virus growth and reactivation from latency in tonsils of infected calves, J. Clin. Microbiol. (2005) 43:393-401.

[159] Perng G.C., Maguen B., Jin L., Mott K.R. Osorio N., Slanina S.M., Yukht A., Ghiasi H., Nesburn A.B., Inman M., Henderson G., Jones C., Wechsler S.L., A gene capable of blocking apoptosis can substitute for the herpes simplex virus type 1 latencyassociated transcript gene and restore wildtype reactivation levels, J. Virol. (2002) 7:1224-1235.

[160] Perrin B., Perrin M., Moussa A., Coudert M., Evaluation of a commercial gE blocking ELISA test for detection of antibodies to infectious bovine rhinotracheitis virus, Vet. Rec. (1996) 138:520.

[161] Poffenberger K.L., Roizman B., A noninverting genome of a viable herpes simplex virus 1: presence of head-to-tail linkages in packaged genomes and requirements for circularization after infection, J. Virol. (1985) 53:587-595.

[162] Rebordosa X., Pinol J., Perez-Pons J.A., Lloberas J., Naval J., Serra-Hartmann X., Espuna E., Querol E., Glycoprotein E of bovine herpesvirus type 1 is involved in virus transmission by direct cell-to-cell spread, Virus Res. (1996) 45:59-68.

[163] Reddy P.S., Idamakanti N., Chen Y., Whale T., Babiuk L.A., Mehtali M., Tikoo S.K., Replication-defective bovine adenovirus type 3 as an expression vector, J. Virol. (1999) 73:9137-9144.

[164] Reynolds A.E., Wills E.G., Roller R.J., Ryckman B.J., Baines J.D., Ultrastructural localization of the herpes simplex virus type 1 UL31, UL34, and US3 proteins suggests specific roles in primary envelopment and egress of nucleocapsids, J. Virol. (2002) 76:8939-8952. 
[165] Reynolds A.E., Liang L., Baines J.D., Conformational changes in the nuclear lamina induced by herpes simplex virus type 1 require genes $\mathrm{U}(\mathrm{L}) 31$ and $\mathrm{U}(\mathrm{L}) 34, \mathrm{~J}$. Virol. (2004) 78:5564-5575.

[166] Rijsewijk F.A., Kaashoek M.J., Langeveld J.P., Meloen R., Judek J., BienkowskaSzewczyk K., Maris-Veldhuis M.A., van Oirschot J.T., Epitopes on glycoprotein C of bovine herpesvirus-1 (BHV-1) that allow differentiation between BHV-1.1 and BHV-1.2 strains, J. Gen. Virol. (1999) 80:1477-1483.

[167] Rock D., Lokensgard J., Lewis T., Kutish G., Characterization of dexamethasoneinduced reactivation of latent bovine herpesvirus 1, J. Virol. (1992) 66:2484-2490.

[168] Roels S., Charlier G., Letellier C., Meyer G., Schynts F., Kerkhofs P., Thiry E., Vanopdenbosch E., Natural case of bovine herpesvirus 1 meningoencephalitis in an adult cow, Vet. Rec. (2000) 146:586-588.

[169] Roizman B., Knipe M.D., Herpes simplex virus and their replication, Lippincott Williams and Wilkins, Philadelphia, 2000.

[170] Saira K., Jones C., BHV-1 gene encoding infected cell protein (BICP0) inhibits antiviral signaling by inducing IRF3 degradation, in proceedings of the 31st International Herpesvirus Workshop, Seattle, 2006, abstract 8.39.

[171] Saydam O., Abril C., Vogt B., Ackermann M., Schwyzer M., Transactivator protein BICP0 of bovine herpesvirus 1 (BHV-1) is blocked by prostaglandin D2 (PGD2), which points to a mechanism for PGD2mediated inhibition of $\mathrm{BHV}-1$ replication, J. Virol. (2004) 78:3805-3810.

[172] Saydam O., Steiner F., Vogt B., Schwyzer M., Host cell targets of immediate-early protein BICP22 of bovine herpesvirus 1 , Vet. Microbiol. (2006) 113:185-192.

[173] Schang L.M., Hossain A., Jones C., The latency-related gene of bovine herpesvirus 1 encodes a product which inhibits cell cycle progression, J. Virol. (1996) 70:38073814.

[174] Schroder C., Linde G., Fehler F., Keil G.M., From essential to beneficial: glycoprotein D loses importance for replication of bovine herpesvirus 1 in cell culture, J. Virol. (1997) 71:25-33.

[175] Schroder C., Keil G.M., Bovine herpesvirus 1 requires glycoprotein $\mathrm{H}$ for infectivity and direct spreading and glycoproteins $\mathrm{gH}(\mathrm{W} 450)$ and $\mathrm{gB}$ for glycoprotein
D-independent cell-to-cell spread, J. Gen. Virol. (1999) 80:57-61.

[176] Schroeder R.J., Moys M.D., An acute respiratory infection of dairy cattle, J. Am. Vet. Med. Assoc. (1954) 125:471-472.

[177] Schumacher D., Tischer B.K., Trapp S., Osterrieder N., The protein encoded by the US3 orthologue of Marek's disease virus is required for efficient de-envelopment of perinuclear virions and involved in actin stress fiber breakdown, J. Virol. (2005) 79:3987-3997.

[178] Schwyzer M., Ackermann M., Molecular virology of ruminant herpesviruses, Vet. Microbiol. (1996) 53:17-29.

[179] Schwyzer M., Styger D., Vogt B., Lowery D.E., Simard C., LaBoissiere S., Misra V., Vlcek C., Paces V., Gene contents in a $31-\mathrm{kb}$ segment at the left genome end of bovine herpesvirus-1, Vet. Microbiol. (1996) 53:67-77.

[180] Schynts F., Meurens F., Muylkens B., Epstein A., McVoy M., Thiry E., Réplication, clivage-encapsidation et recombinaison de 1'ADN des herpèsvirus, Virologie (2002) 6:343-352.

[181] Schynts F., McVoy M.A., Meurens F., Detry B., Epstein A.L., Thiry E., The structures of bovine herpesvirus 1 virion and concatemeric DNA: implications for cleavage and packaging of herpesvirus genomes, Virology (2003) 314:326-335.

[182] Schynts F., Meurens F., Detry B., Vanderplasschen A., Thiry E., Rise and survival of bovine herpesvirus 1 recombinants after primary infection and reactivation from latency, J. Virol. (2003) 77:12535-12542.

[183] Severini A., Morgan A.R., Tovell D.R., Tyrrell D.L., Study of the structure of replicative intermediates of HSV-1 DNA by pulsed-field gel electrophoresis, Virology (1994) 200:428-435.

[184] Severini A., Scraba D.G., Tyrrell D.L., Branched structures in the intracellular DNA of herpes simplex virus type 1, J. Virol. (1996) 70:3169-3175.

[185] Sheffy B.E., Davies D.H., Reactivation of a bovine herpesvirus after corticosteroid treatment, Proc. Soc. Exp. Biol. Med. (1972) 140:974-976.

[186] Simard C., Langlois I., Styger D., Vogt B., Vlcek C., Chalifour A., Trudel M., Schwyzer M., Sequence analysis of the UL39, UL38, and UL37 homologues of bovine herpesvirus 1 and expression studies of UL40 and UL39, the subunits of 
ribonucleotide reductase, Virology (1995) 212:734-740.

[187] Smith G.A., Young P.L., Reed K.C., Emergence of a new bovine herpesvirus 1 strain in Australian feedlots, Arch. Virol. (1995) 140:599-603.

[188] Smith V.W., Coakley W., Maker D., Transmission of a genital isolate of bovine herpesvirus 1 to calves by the respiratory route, Aust. Vet. J. (1980) 56:302-304.

[189] Solis-Calderon J.J., Segura-Correa V.M., Segura-Correa J.C., Alvarado-Islas A., Seroprevalence of and risk factors for infectious bovine rhinotracheitis in beef cattle herds of Yucatan, Mexico, Prev. Vet. Med. (2003) 57:199-208.

[190] Spilki F.R., Esteves P.A., de Lima M., Franco A.C., Chiminazzo C., Flores E.F., Weiblen R., Driemeier D., Roehe P.M., Comparative pathogenicity of bovine herpesvirus 1 (BHV-1) subtypes 1 (BHV-1.1) and 2a (BHV-1.2a), Pesquisa Veterinaria Brasileira (2004) 24:43-49.

[191] Spilki F.R., Esteves P.A., da Silva A.D., Franco A.C., Rijsewijk F.A., Roehe P.M., A monoclonal antibody-based ELISA allows discrimination between responses induced by bovine herpesvirus subtypes 1 (BoHV1.1) and 2 (BoHV-1.2), J. Virol. Methods (2005) 129:191-193.

[192] Spurzem J.R., Raz M., Ito H., Kelling C.L., Stine L.C., Romberger D.J., Rennard S.I., Bovine herpesvirus-1 infection reduces bronchial epithelial cell migration to extracellular matrix proteins, Am. J. Physiol. (1995) 268:L214-220.

[193] Thiry E., Saliki J., Schwers A., Pastoret P.P., Parturition as a stimulus of IBR virus reactivation, Vet. Rec. (1985) 116:599-600.

[194] Thiry E., Saliki J., Bublot M., Pastoret P.P., Reactivation of infectious bovine rhinotracheitis virus by transport, Comp. Immunol. Microbiol. Infect. Dis. (1987) 10:59-63.

[195] Thiry E., Meurens F., Muylkens B., McVoy M., Gogev S., Thiry J., Vanderplasschen A., Epstein A., Keil G., Schynts F., Recombination in alphaherpesviruses, Rev. Med. Virol. (2005) 15:89-103.

[196] Thiry E., Muylkens B., Meurens F., Gogev S., Thiry J., Vanderplasschen A., Schynts F., Recombination in the alphaherpesvirus bovine herpesvirus 1, Vet. Microbiol. (2006) 113:171-177.

[197] Thiry J., Keuser V., Muylkens B., Meurens F., Gogev S., Vanderplasschen A., Thiry E., Ruminant alphaherpesviruses related to bovine herpesvirus 1, Vet. Res. (2006) 37:169-190.

[198] Tikoo S.K., Campos M., Babiuk L.A., Bovine herpesvirus 1 (BHV-1): biology, pathogenesis, and control, Adv. Virus Res. (1995) 45:191-223.

[199] Toussaint J.F., Coen L., Letellier C., Dispas M., Gillet L., Vanderplasschen A., Kerkhofs P., Genetic immunisation of cattle against bovine herpesvirus 1: glycoprotein $\mathrm{gD}$ confers higher protection than glycoprotein $\mathrm{gC}$ or tegument protein VP8, Vet. Res. (2005) 36:529-544.

[200] Toussaint J.F., Letellier C., Paquet D., Dispas M., Kerkhofs P., Prime-boost strategies combining DNA and inactivated vaccines confer high immunity and protection in cattle against bovine herpesvirus-1, Vaccine (2005) 23:5073-5081.

[201] Trapp S., Osterrieder N., Keil G.M., Beer M., Mutagenesis of a bovine herpesvirus type 1 genome cloned as an infectious bacterial artificial chromosome: analysis of glycoprotein $\mathrm{E}$ and $\mathrm{G}$ double deletion mutants, J. Gen. Virol. (2003) 84:301-306.

[202] Van der Meulen K., Caij B., Pensaert M., Nauwynck H., Absence of viral envelope proteins in equine herpesvirus 1infected blood mononuclear cells during cell-associated viremia, Vet. Microbiol. (2006) 113:265-273.

[203] Van Drunen Littel-van den Hurk S., Tikoo S.K., Liang X., Babiuk L.A., Bovine herpesvirus-1 vaccines, Immunol. Cell Biol. (1993) 71:405-420.

[204] Van Drunen Littel-van den Hurk S., Van Donkersgoed J., Kowalski J., van den Hurk J.V., Harland R., Babiuk L.A., Zamb T.J., A subunit gIV vaccine, produced by transfected mammalian cells in culture, induces mucosal immunity against bovine herpesvirus-1 in cattle, Vaccine (1994) 12:1295-1302.

[205] Van Drunen Littel-van den Hurk S., Garzon S., van den Hurk J.V., Babiuk L.A., Tijssen $\mathrm{P}$., The role of the major tegument protein VP8 of bovine herpesvirus-1 in infection and immunity, Virology (1995) 206:413425 .

[206] Van Drunen Littel-van den Hurk S., Rationale and perspectives on the success of vaccination against bovine herpesvirus1, Vet. Microbiol. (2006) 113:275-282.

[207] Van Engelenburg F.A., Kaashoek M.J., van Oirschot J.T., Rijsewijk F.A., A glycoprotein $\mathrm{E}$ deletion mutant of bovine herpesvirus 1 infects the same limited number 
of tissues in calves as wild-type virus, but for a shorter period, J. Gen. Virol. (1995) 76:2387-2392.

[208] Van Schaik G., Shoukri M., Martin S.W., Schukken Y.H., Nielen M., Hage J.J., Dijkhuizen A.A., Modeling the effect of an outbreak of bovine herpesvirus type 1 on herd-level milk production of Dutch dairy farms, J. Dairy Sci. (1999) 82:944-952.

[209] Van Schaik G., Risk and economics of disease introduction to dairy farms, Tijdschr. Diergeneeskd. (2001) 126:414-418 (in Dutch).

[210] Van Schaik G., Schukken Y.H., Nielen M., Dijkhuizen A.A., Benedictus G., Risk factors for introduction of BHV1 into BHV1free Dutch dairy farms: a case-control study, Vet. Q. (2001) 23:71-76.

[211] Van Schaik G., Schukken Y.H., Nielen M., Dijkhuizen A.A., Barkema H.W., Benedictus G., Probability of and risk factors for introduction of infectious diseases into Dutch SPF dairy farms: a cohort study, Prev. Vet. Med. (2002) 54:279-289.

[212] Van Oirschot J.T., Kaashoek M.J., MarisVeldhuis M.A., Weerdmeester K., Rijsewijk F.A.M., An enzyme-linked immunosorbent assay to detect antibodies against glycoprotein $\mathrm{gE}$ of bovine herpesvirus 1 allows differentiation between infected and vaccinated cattle, J. Virol. Methods (1997) 67:23-34.

[213] Vlcek C., Benes V., Lu Z., Kutish G.F., Paces V., Rock D., Letchworth G.J., Schwyzer M., Nucleotide sequence analysis of a 30-kb region of the bovine herpesvirus 1 genome which exhibits a colinear gene arrangement with the UL21 to UL4 genes of herpes simplex virus, Virology (1995) 210:100-108.

[214] Vonk Noordegraaf A., Labrovic A., Frankena K., Pfeiffer D.U., Nielen M., Simulated hazards of loosing infection-free status in a Dutch BHV1 model, Prev. Vet. Med. (2004) 62:51-58.

[215] Warren L.M., Babiuk L.A., Campos M., Effects of BHV-1 on PMN adhesion to bovine lung endothelial cells, Vet. Immunol. Immunopathol. (1996) 55:73-82.

[216] Whetstone C.A., Miller J.M., Two different strains of an alphaherpesvirus can establish latency in the same tissue of the host animal: evidence from bovine herpesvirus 1, Arch. Virol. (1989) 107:27-34.

[217] Whetstone C.A., Miller J.M., Seal B.S., Bello L.J., Lawrence W.C., Latency and reactivation of a thymidine kinase-negative bovine herpesvirus 1 deletion mutant, Arch. Virol. (1992) 122:207-214.

[218] Wild P., Engels M., Senn C., Tobler K., Ziegler U., Schraner E.M., Loepfe E., Ackermann M., Mueller M., Walther P., Impairment of nuclear pores in bovine herpesvirus 1-infected MDBK cells, J. Virol. (2005) 79:1071-1083.

[219] Winkler M.T., Doster A., Jones C., Bovine herpesvirus 1 can infect CD4(+) T lymphocytes and induce programmed cell death during acute infection of cattle, J. Virol. (1999) 73:8657-8668.

[220] Winkler M.T., Doster A., Jones C., Persistence and reactivation of bovine herpesvirus 1 in the tonsils of latently infected calves, J. Virol. (2000) 74:5337-5346.

[221] Wirth U.V., Gunkel K., Engels M., Schwyzer M., Spatial and temporal distribution of bovine herpesvirus 1 transcripts, J. Virol. (1989) 63:4882-4889.

[222] Wirth U.V., Vogt B., Schwyzer M., The three major immediate-early transcripts of bovine herpesvirus 1 arise from two divergent and spliced transcription units, J. Virol. (1991) 65:195-205.

[223] Wirth U.V., Fraefel C., Vogt B., Vlcek C., Paces V., Schwyzer M., Immediate-early RNA 2.9 and early RNA 2.6 of bovine herpesvirus 1 are 3' coterminal and encode a putative zinc finger transactivator protein, $\mathrm{J}$. Virol. (1992) 66:2763-2772.

[224] Wu S.X., Zhu X.P., Letchworth G.J., Bovine herpesvirus 1 glycoprotein $\mathrm{M}$ forms a disulfide-linked heterodimer with the U(L)49.5 protein, J. Virol. (1998) 72:30293036.

[225] Wyler R., Engels M., Schwyzer M., Infectious bovine rhinotracheitis/vuvlvovaginitis, Kluwer academic publishers, Boston, Dordrecht, London, 1989.

[226] Zakhartchouk A.N., Pyne C., Mutwiri G.K., Papp Z., Baca-Estrada M.E., Griebel P., Babiuk L.A., Tikoo S.K., Mucosal immunization of calves with recombinant bovine adenovirus-3: induction of protective immunity to bovine herpesvirus-1, J. Gen. Virol. (1999) 80:1263-1269.

[227] Zheng C., Brownlie R., Babiuk L.A., van Drunen Littel-van den Hurk S., Characterization of nuclear localization and export signals of the major tegument protein VP8 of bovine herpesvirus-1, Virology (2004) 324:327-339. 